Terzopoulos, N, Hayatleh, K, Sebu, C, Lidgey, FJ, Ben-Esmael, M, Tammam, AA and Barker, S

Analysis and design of a high precision- high output impedance tissue current driver for medical applications

Terzopoulos, N, Hayatleh, K, Sebu, C, Lidgey, FJ, Ben-Esmael, M, Tammam, AA and Barker, S (2014) Analysis and design of a high precision- high output impedance tissue current driver for medical applications. Journal of Circuits, Systems, and Computers, 23 (8).

doi: 10.1142/S021812661450114X

This version is available: https://radar.brookes.ac.uk/radar/items/ccd2caa5-4ad9-402a-944b-4c3a8ecdcabc/1/

Available on RADAR: February 2016

Copyright (C) and Moral Rights are retained by the author(s) and/ or other copyright owners. A copy can be downloaded for personal non-commercial research or study, without prior permission or charge. This item cannot be reproduced or quoted extensively from without first obtaining permission in writing from the copyright holder(s). The content must not be changed in any way or sold commercially in any format or medium without the formal permission of the copyright holders.

This document is the post print version of the journal article. Some differences between the published version and this version may remain and you are advised to consult the published version if you wish to cite from it. 


\title{
Analysis and design of a high precision- high output impedance tissue current driver for medical applications
}

\author{
N. Terzopoulos, K. Hayatleh, C. Sebu, F. J. Lidgey, M. Ben-Esmael, A. A. Tammam and \\ S Barker \\ Oxford Brookes University, Wheatley Campus, Oxford, OX33 1HX, UK
}

khayatleh@brookes.ac.uk

\begin{abstract}
This paper describes the design and operation of a high output impedance tissue current driver circuit, for use in medical electronics, such as Electrical Impedance Tomography (EIT). This novel architecture was designed for implementation in bipolar technology, to meet the specifications for EIT, namely operating frequency range 10 $\mathrm{kHz}-1 \mathrm{MHz}$ with a target output resistance of $16 \mathrm{M} \Omega$. Simulation results are presented, showing that the current source more than met the minimum specification for EIT.
\end{abstract}

Keywords: (Current Sources; Electrical Impedance Tomography, Medical Instrumentation, High Output Impedance Current Drive Circuits)

\section{Introduction}

In recent years current sources and current drive circuits have been used widely in medical instrumentation, particularly in the design of Electrical Impedance Tomography (EIT) systems [1-8]. EIT is a non-invasive, portable, low-cost technology developed to image the distribution of electrical properties, conductivity or permittivity within an object from the measurements of electric currents and voltages at the surface. Since different materials display different electrical properties, EIT can also be used as a method of industrial, geophysical and medical imaging [6].

One of the most promising medical applications of EIT is lung function monitoring of mechanically-ventilated patients [9-12]. Since a typical data acquisition time for this application extends from hours to a few days, one major problem is the maintenance of good electrode-skin contact. EIT typically uses Electrocardiogram (ECG) or Electroencephalography (EEG) type electrodes, which are placed on the skin with a conducting gel to improve electrical contact. When injecting electrical currents, a thin high impedance layer forms the electrode-electrolyte interface due to certain electrochemical processes. Patient movements, staff manipulations, changes in the sweat ducts, drying of the electrode gel and partial regeneration of the skin under the electrodes can lead to large variations in the contact impedance, e.g. from $1 \mathrm{k} \Omega$ to $100 \mathrm{k} \Omega$ in milliseconds [15-16]. This is a serious concern for medical EIT applications, as such high and uncontrollable changes in impedance will adversely affect the acquired EIT data. 
Therefore, EIT systems designed with a very high output impedance current source will be less affected by these variations. In order to achieve $0.1 \%$ accuracy the output impedance must be greater than $16 \mathrm{M} \Omega$ for the frequency range of the excitation current [17]. In medical applications of EIT the excitation frequency is normally in the range of $10 \mathrm{kHz}-50 \mathrm{kHz}$, but in some instances frequencies up to $1 \mathrm{MHz}$ is used. Thus the target specification of a biomedical impedance measuring circuit is $16 \mathrm{M} \Omega$ at $1 \mathrm{MHz}$. In current source design for EIT the authors decided to use bipolar technology as it offers better performance than CMOS in providing higher-bandwidth operation with low-frequency noise performance at low quiescent current. Moreover, bipolar transistors inherently offer better matching, resulting in lower offset voltages, a very important factor for current sources [1].

\section{Current Sources critical review}

There have been several techniques developed to improve the output impedance of a current source and in this section we will briefly review some of them .

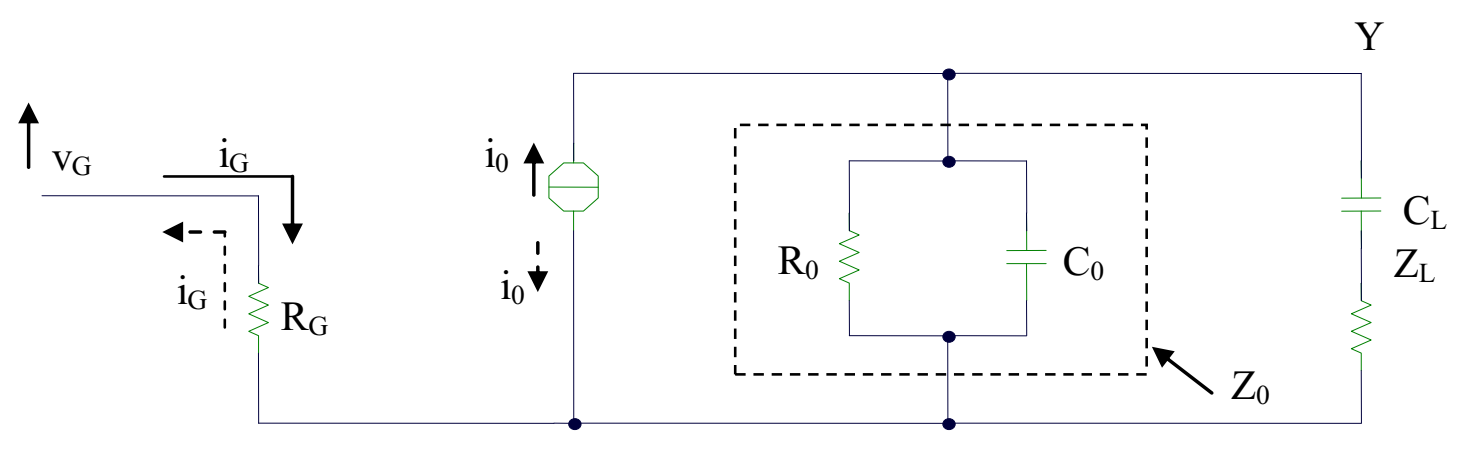

Figure 1: Elementary system schematic

Fig. 1 shows a bipolar type of a voltage controlled current source (VCCS) with an output impedance of $Z_{0}$ feeding a tissue sample of impedance $Z_{L}$ through a blocking capacitor $\mathrm{C}_{\mathrm{L}}$ which is required for safety reasons. The problem with this simple scheme is that the DC level at the point labeled $Y$ is not well defined, causing mismatches, and eventually, false readings. Howland [5] developed a design in which the load is grounded, but this involves a network in which the resistors must be very well matched for the proper function of the configuration (see Fig. 2). Mismatches could cause the output impedance to be lower than desired. This design also has a possibly more significant drawback, in that it cannot be used at high frequencies, because the design incorporates both positive and negative feedback leading to instability problems. 


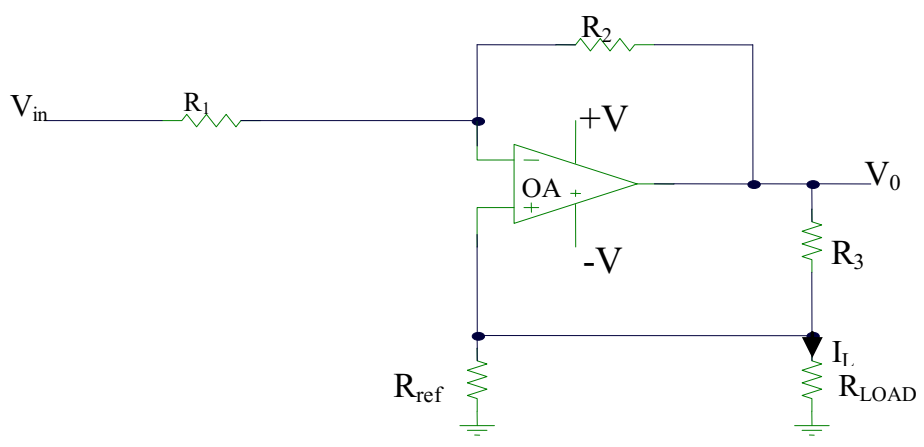

Figure 2: The Howland circuit

An alternative scheme was first developed by Graeme [14] who used a complementary pair of field effect transistors (FETs) for the current mirror role. However, this circuit also required precise resistor matching. To overcome this difficulty, Hart and Barker [15] proposed a very different current sensing configuration. The circuit includes a Class-B output amplifier in order to overcome resistor mismatch problems, and achieves very good high output impedance performance. Although the Hart and Barker [15] configuration had very good characteristics, it suffered from cross-over distortion inherent in all class-B amplifiers. This problem was addressed by Rao and Haslett [16] who proved that the high frequency performance can be improved and the output impedance can be increased by using a class- $\mathrm{AB}$ amplifier.

The most common type of a current controlled current source (CCCS) consists of an NPN transistor connected in common-emitter configuration, with emitter degeneration or a DC constant current source in the emitter lead. This layout can give an output resistance up to several hundred thousand ohms with an operating collector current of $1 \mathrm{~mA}$. However, this is not high enough for the target specification of $1 \mathrm{M} \Omega$ at $1 \mathrm{MHz}$ for EIT systems. In order to meet the high frequency and high impedance requirements of EIT system, alternative circuit techniques have been studied and developed in this paper.

\section{Tissue Current Driver System Design and Operation}

The tissue current driver system schematic diagram presented in Fig. 3 shows four interconnected sub-units A, B, C, D. For an initial description of the system operation, let us assume that unit $\mathrm{D}$, below the horizontal dotted line $\mathrm{ab}$, is disconnected. Unit $\mathrm{A}$ is essentially a unity-gain voltage-follower with the non-inverting input connected to ground. The input current to unit $\mathrm{A}$ is produced by a sinusoidal voltage signal, $\mathrm{v}_{\mathrm{G}}$, of radian frequency $\omega$, applied via capacitor $C_{I N}$ and series resistor $R_{G}$ to input terminal $X$. To an input signal applied at $X$, the equivalent input circuit is a resistor $R_{I}$ connected to a virtual earth point. Thus, if $\mathrm{R}_{\mathrm{G}}$ is much greater than $\mathrm{R}_{\mathrm{I}}$, and also much greater than the impedance, $1 / \omega \mathrm{C}_{\mathrm{IN}}$, of capacitor $\mathrm{C}_{\mathrm{IN}}$ at any signal frequency of interest, then the input current is $i_{G}=v_{G} / R_{G}$. 
Unit A produces two output currents $i_{P}$ and $i_{N}$ related as follows:

$$
\left(\mathrm{i}_{\mathrm{P}}-\mathrm{i}_{\mathrm{N}}\right)=-\mathrm{i}_{\mathrm{G}}=-\mathrm{v}_{\mathrm{G}} / \mathrm{R}_{\mathrm{G}}
$$

Units B and C are, respectively, PNP and NPN current-mirrors having nominal currenttransfer ratios of one and high output impedances. Hence at point $Y$ :

$$
\mathrm{i}_{\mathrm{L}}=\left(\mathrm{i}_{\mathrm{P}}-\mathrm{i}_{\mathrm{N}}\right)
$$

The tissue sample, $T$, of impedance $Z_{L}$, is AC- coupled to current- mirror output point $\mathrm{Y}$ by capacitor $C_{L}$, thus ensuring that no DC is applied to it.

Resistor $R_{Z}$ is necessary (if unit $\mathrm{D}$ is not present) in order to define the DC output voltage, $\mathrm{V}_{0}$, at point $\mathrm{Y}$, so that units $\mathrm{B}$ and $\mathrm{C}$ always operate in the linear region. This requires that $\left|\mathrm{V}_{\mathrm{CC}}-\mathrm{V}_{\text {O(peak) }}\right|>\mathrm{V}_{\mathrm{K}}$, where $\mathrm{V}_{\mathrm{K}}$ is the minimum allowed voltage between the output terminals of $\mathrm{B}$ or $\mathrm{C}$, and $\mathrm{V}_{\mathrm{CC}}$ is the $\mathrm{DC}$ supplied voltage to the circuit.

If $\mathrm{C}_{\mathrm{L}}$ is chosen such that $1 / \omega \mathrm{C}_{\mathrm{L}} \ll$, then $\mathrm{v}_{0 \text { (peak) }} \approx \mathrm{V}_{0}+\mathrm{v}_{\mathrm{T}(\text { peak })}$ and we must have

$$
\mathrm{V}_{0}<\left|\mathrm{V}_{\mathrm{CC}}-\mathrm{V}_{\mathrm{K}}-\mathrm{V}_{\mathrm{T}(\text { peak })}\right|
$$

If $\mathrm{V}_{\mathrm{CC}}=5 \mathrm{~V}$ and $\mathrm{V}_{\mathrm{T}(\text { peak })}=\mathrm{V}_{\mathrm{K}}=2 \mathrm{~V}$, then $\mathrm{V}_{0}=1 \mathrm{~V}$. Suppose the mismatch in the $\mathrm{DC}$ value of $\left(i_{P}-i_{N}\right)$ is $40 \mu \mathrm{A}$, when $i_{P}$ and $i_{N}$ are each nominally $1 \mathrm{~mA}$, this shows that $\mathrm{R}_{\mathrm{Z}}=25 \mathrm{k} \Omega$. This is an unacceptably small source resistance seen by $\mathrm{T}$ (tissue sample), i.e. about three orders of magnitude less than the achievable incremental output resistance of $B$ or $C$. A solution to the problem is to remove $R_{Z}$ and use a feedback network, unit $D$, which is directly coupled to point $\mathrm{Y}$ via a simple first-order low-pass filter with $\mathrm{R}_{\mathrm{F}}$ and

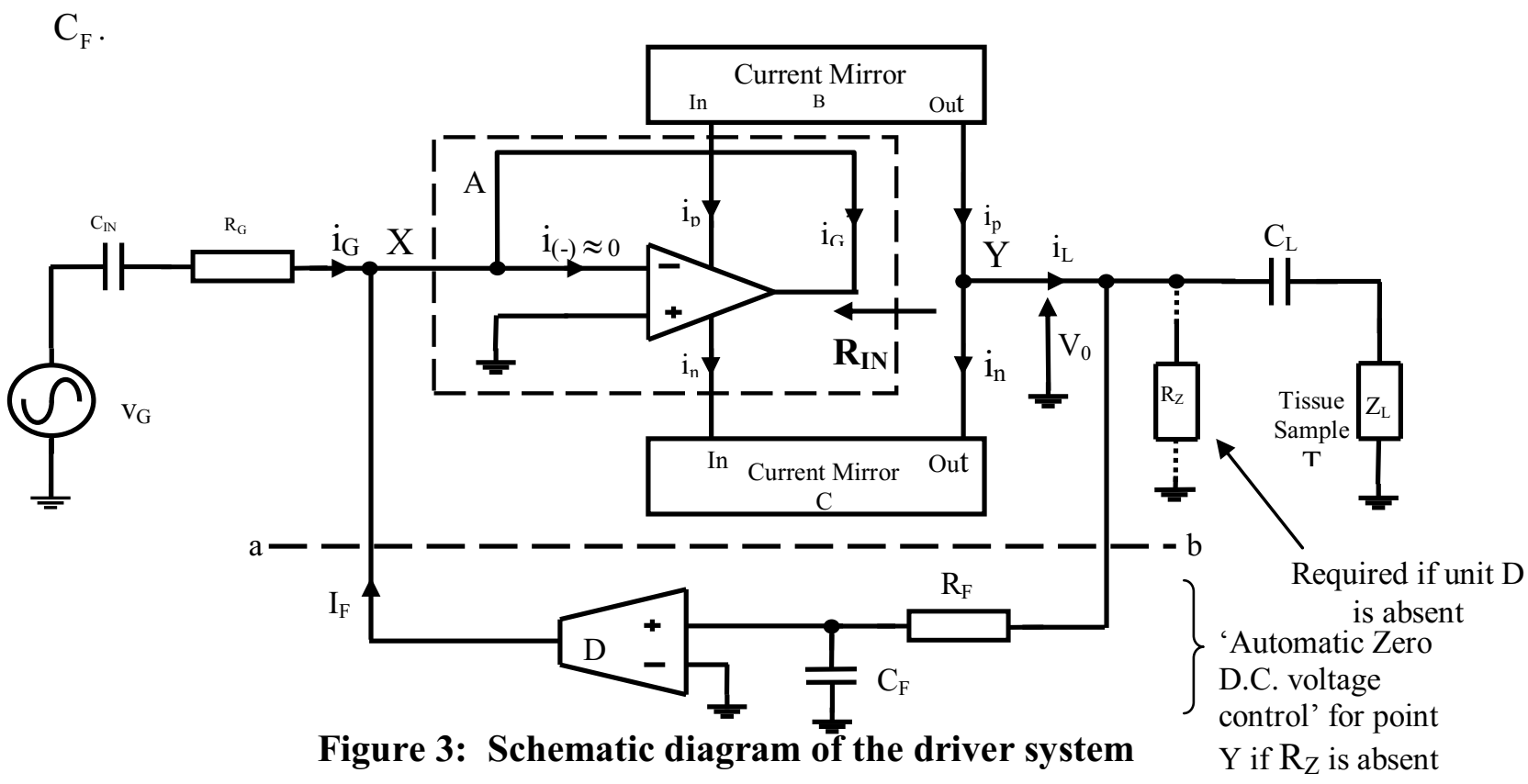


The role of the very high input resistance transconductance amplifier unit $\mathrm{D}$ is to compare $V_{0}$ with earth potential and supply an output current, $I_{F}$, whose magnitude and polarity are sufficient to reduce $\mathrm{V}_{0}$ to near-zero voltage, thus guaranteeing the maximum possible symmetrical output swing at point $Y$. This will thus equalize the DC output current of units B and C. If these (nominally equal) currents differ by $\Delta \mathrm{I}$, then $\mathrm{V}_{0}=\Delta \mathrm{I} / \mathrm{G}_{\mathrm{M}}$, where $\mathrm{G}_{\mathrm{M}}$ is the transconductance of $\mathrm{D}$. Hence, if $\Delta \mathrm{I}=40 \mu \mathrm{A}$ and $\mathrm{G}_{\mathrm{M}}=20 \mu \mathrm{A} / \mathrm{mV}$, then $\mathrm{V}_{0}=2 \mathrm{mV}$.The design of A is relatively straightforward [17], and is presented in Section 3. In order to obtain a high output resistance for units B and C, we employ a modified version of a circuit technique first introduced by Baxandall and Swallow (B\&S) [18]. Unit $\mathrm{D}$ is a transconductance amplifier of conventional design [19] but, additionally, has MOSFET voltage-follower input stages to provide a very high DC input resistance, see Section 5. The transfer characteristic of a transconductance amplifier [19] is:

$$
\mathrm{G}_{\mathrm{M}} \approx \frac{\mathrm{I}}{2 \mathrm{~V}_{\mathrm{T}}},
$$

where, $\mathrm{I}$ is the biasing current of unit $\mathrm{D}$ and $\mathrm{V}_{\mathrm{T}}$ is the 'thermal voltage' $(\approx 25 \mathrm{mV}$ at room temperature).

\section{Design of Input Stage (Unit A)}

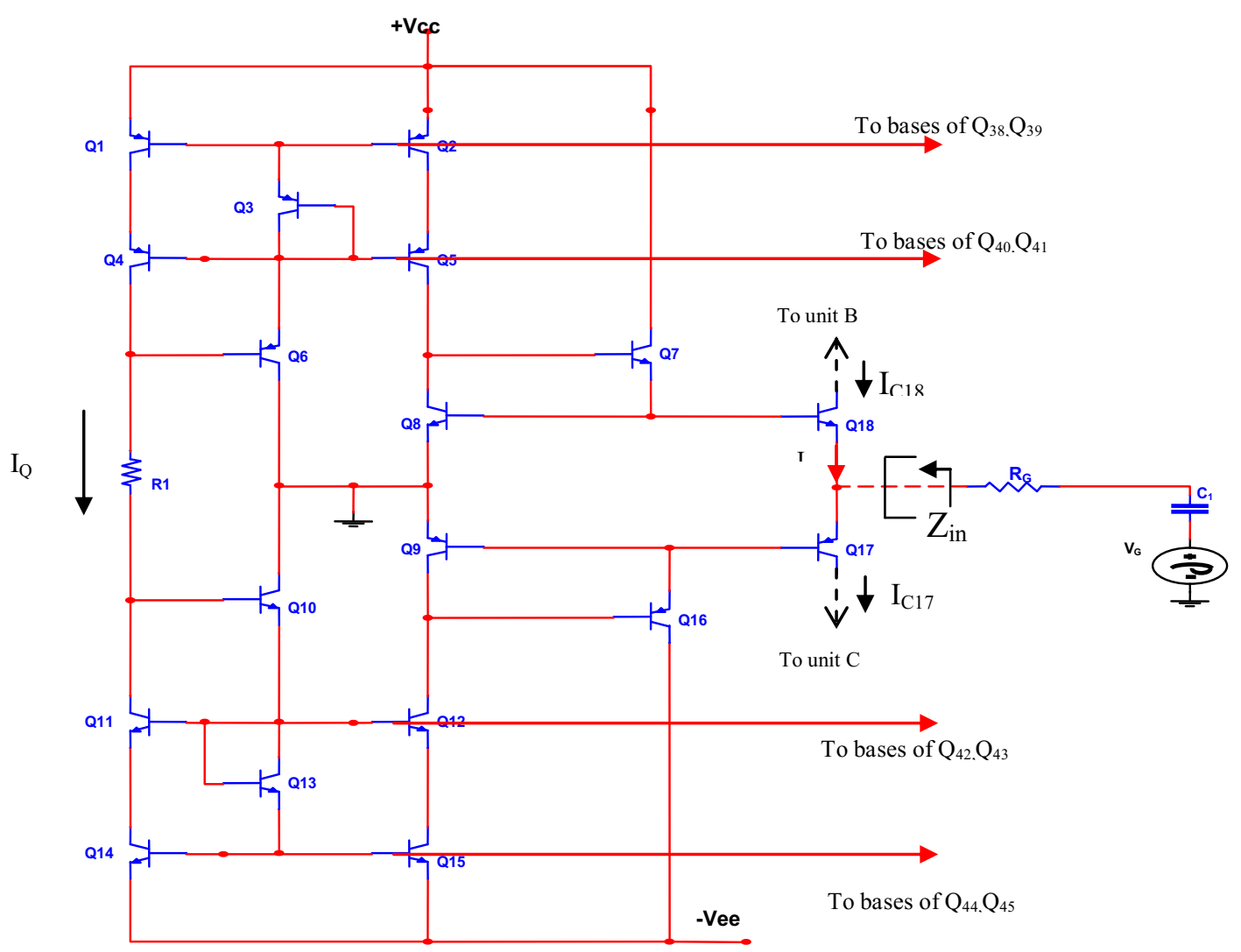

Figure 4: Circuit diagram of unit A of Fig.3 [20-22] 
In Fig. 4 the complementary '6-pack' current mirrors [20] provide biasing currents $\mathrm{I}_{\mathrm{A}}$ and $\mathrm{I}_{\mathrm{B}}$ from the system operating current, $\mathrm{I}_{\mathrm{Q}}(=1.1 \mathrm{~mA})$ provided by resistor $\mathrm{R}_{1}$. The emitterfollower transistors $\mathrm{Q}_{7}$ and $\mathrm{Q}_{16}$ ensure that $\mathrm{I}_{\mathrm{A}}$ and $\mathrm{I}_{\mathrm{B}}$ are the collector currents of $\mathrm{Q}_{8}$ and $\mathrm{Q}_{9}$, respectively, and that the output bipolar junction transistors (BJTs) $\mathrm{Q}_{18}$ (feeding unit $\mathrm{B}$ ) and $\mathrm{Q}_{17}$ (feeding unit C) operate in class B mode.

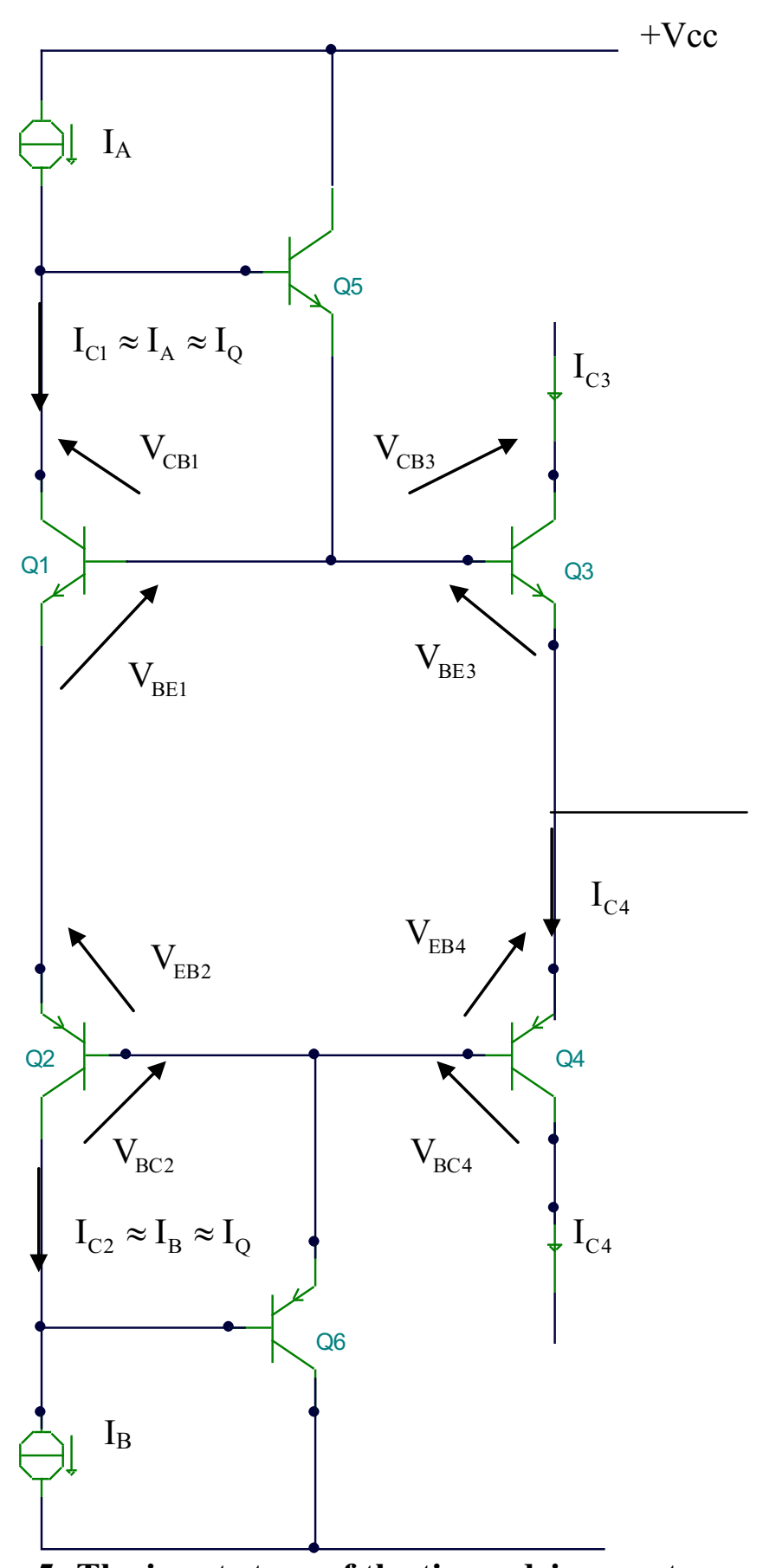

Figure 5: The input stage of the tissue driver system 
The DC potential, $\mathrm{V}_{\mathrm{OS}}$, of that point differs from zero volts by only a small amount due to the balance in the base-emitter voltages of $\mathrm{Q}_{8}, \mathrm{Q}_{18}$ and $\mathrm{Q}_{9}, \mathrm{Q}_{17}$. Fig. 5 presents the input stage of the tissue driver system, which can be used to derive a full expression for $\mathrm{V}_{\mathrm{OS}}$.

The current $\mathrm{I}_{\mathrm{Cl}}$ in Fig. 5 can be expressed as:

$$
\mathrm{I}_{\mathrm{C} 1}=\mathrm{I}_{\mathrm{SN} 1}\left(1+\frac{\mathrm{V}_{\mathrm{CB} 1}}{\mathrm{~V}_{\mathrm{AN}}}\right) \exp \left(\frac{\mathrm{V}_{\mathrm{BE} 1}}{\mathrm{~V}_{\mathrm{T}}}\right)
$$

Consequently,

$$
\mathrm{V}_{\mathrm{BE} 1}=\mathrm{V}_{\mathrm{T}} \log _{\mathrm{e}} \frac{\mathrm{I}_{\mathrm{C} 1}}{\mathrm{I}_{\mathrm{SN} 1}\left(1+\frac{\mathrm{V}_{\mathrm{CB} 1}}{\mathrm{~V}_{\mathrm{AN}}}\right)} \approx \mathrm{V}_{\mathrm{T}} \log _{\mathrm{e}} \frac{\mathrm{I}_{\mathrm{A}}}{\mathrm{I}_{\mathrm{SN} 1}\left(1+\frac{\mathrm{V}_{\mathrm{CB} 1}}{\mathrm{~V}_{\mathrm{AN}}}\right)}
$$

Following the approach above, similar expressions can be derived for $\mathrm{V}_{\mathrm{BE} 3}, \mathrm{~V}_{\mathrm{EB} 2}$ and $\mathrm{V}_{\mathrm{EB} 4}$, namely:

$$
\begin{aligned}
& \mathrm{V}_{\mathrm{BE} 3}=\mathrm{V}_{\mathrm{T}} \log _{\mathrm{e}} \frac{\alpha_{\mathrm{n}} \mathrm{I}_{\mathrm{X}}}{\mathrm{I}_{\mathrm{SN} 3}\left(1+\frac{\mathrm{V}_{\mathrm{CB} 3}}{\mathrm{~V}_{\mathrm{AN}}}\right),} \\
& \mathrm{V}_{\mathrm{EB} 2} \approx \mathrm{V}_{\mathrm{T}} \log _{\mathrm{e}} \frac{\mathrm{I}_{\mathrm{B}}}{\mathrm{I}_{\mathrm{SP} 2}\left(1+\frac{\mathrm{V}_{\mathrm{BC} 2}}{\mathrm{~V}_{\mathrm{AP}}}\right),} \\
& \mathrm{V}_{\mathrm{EB} 4}=\mathrm{V}_{\mathrm{T}} \log _{\mathrm{e}} \frac{\alpha_{\mathrm{p}} \mathrm{I}_{\mathrm{X}}}{\mathrm{I}_{\mathrm{SP} 4}\left(1+\frac{\mathrm{V}_{\mathrm{BC} 4}}{\mathrm{~V}_{\mathrm{AP}}}\right)},
\end{aligned}
$$

where $\alpha_{n, p}=\frac{1+\beta_{n, p}}{\beta_{n, p}}$ and $\beta_{n}$ and $\beta_{p}$ are the current gains of the BJTs.

Using the above equations and given that:

$$
\mathrm{V}_{\mathrm{BE} 1}+\mathrm{V}_{\mathrm{EB} 2}=\mathrm{V}_{\mathrm{BE} 3}+\mathrm{V}_{\mathrm{EB} 4} \text {, }
$$

we obtain 


$$
\mathrm{I}_{\mathrm{C} 3} \approx \alpha_{\mathrm{N}} \mathrm{I}_{\mathrm{X}}=\sqrt{\frac{\alpha_{\mathrm{n}}}{\alpha_{\mathrm{p}}}} \sqrt{\mathrm{I}_{\mathrm{A}} \mathrm{I}_{\mathrm{B}}} \sqrt{\frac{\left(1+\frac{\mathrm{V}_{\mathrm{CB} 3}}{\mathrm{~V}_{\mathrm{AN}}}\right)\left(1+\frac{\mathrm{V}_{\mathrm{BC} 4}}{\mathrm{~V}_{\mathrm{AP}}}\right)}{\left(1+\frac{\mathrm{V}_{\mathrm{CB} 1}}{\mathrm{~V}_{\mathrm{AN}}}\right)\left(1+\frac{\mathrm{V}_{\mathrm{BC} 2}}{\mathrm{~V}_{\mathrm{AP}}}\right)} \sqrt{\frac{\mathrm{I}_{\mathrm{SN} 3} \mathrm{I}_{\mathrm{SP} 4}}{\mathrm{I}_{\mathrm{SN} 1} \mathrm{I}_{\mathrm{SP} 2}}}}
$$

Hence, the potential at the emitter of $\mathrm{Q}_{3}, \mathrm{~V}_{\mathrm{OS}}$, is given by:

$$
\begin{aligned}
\mathrm{V}_{\mathrm{OS}} & =\left(\mathrm{V}_{\mathrm{BE} 1}-\mathrm{V}_{\mathrm{BE} 3}\right) \\
& \approx \mathrm{V}_{\mathrm{T}} \log _{\mathrm{e}} \sqrt{\left(\frac{\mathrm{I}_{\mathrm{A}}}{\mathrm{I}_{\mathrm{B}}}\right)\left(\frac{\mathrm{I}_{\mathrm{SN} 3}}{\mathrm{I}_{\mathrm{SN} 1}}\right)\left(\frac{\mathrm{I}_{\mathrm{SP} 2}}{\mathrm{I}_{\mathrm{SP} 4}}\right)\left(\frac{\alpha_{\mathrm{n}}}{\alpha_{\mathrm{p}}}\right) \frac{\left(1+\frac{\mathrm{V}_{\mathrm{BC} 2}}{\mathrm{~V}_{\mathrm{AP}}}\right)}{\left(1+\frac{\mathrm{V}_{\mathrm{CB} 1}}{\mathrm{~V}_{\mathrm{AN}}}\right)\left(1+\frac{\mathrm{V}_{\mathrm{CB} 3}}{\mathrm{~V}_{\mathrm{AN}}}\right)\left(1+\frac{\mathrm{V}_{\mathrm{BC} 4}}{\mathrm{~V}_{\mathrm{AP}}}\right)}}
\end{aligned}
$$

For real devices, each of the single ratio terms under the root sign in equation (9) is close to one and, therefore:

$$
\mathrm{V}_{\mathrm{OS}} \approx \mathrm{V}_{\mathrm{T}} \log _{\mathrm{e}} \sqrt{\frac{\left(1+\frac{\mathrm{V}_{\mathrm{BC} 2}}{\mathrm{~V}_{\mathrm{AP}}}\right)}{\left(1+\frac{\mathrm{V}_{\mathrm{CB} 1}}{\mathrm{~V}_{\mathrm{AN}}}\right)\left(1+\frac{\mathrm{V}_{\mathrm{CB} 3}}{\mathrm{~V}_{\mathrm{AN}}}\right)\left(1+\frac{\mathrm{V}_{\mathrm{BC} 4}}{\mathrm{~V}_{\mathrm{AP}}}\right)}}
$$

The Early voltages for NPN and PNP transistors are $\mathrm{V}_{\mathrm{AN}}=90 \mathrm{~V}$ and $\mathrm{V}_{\mathrm{AP}}=23 \mathrm{~V}$, respectively. Since the values of the collector-base voltages are much smaller, the whole term under the root sign is close to one and hence, the value of $V_{O S}$ should be close to zero. The simulated value of $\mathrm{V}_{\mathrm{OS}}$ was $-1.6 \mathrm{mV}$. Looking into the common-emitter point of $\mathrm{Q}_{17}, \mathrm{Q}_{18}$ we see effectively the output impedance of two common-base stages in parallel. At low frequencies the impedance is resistive and given by the following equation:

$$
\mathrm{R}_{\mathrm{I}}=\frac{1}{2}\left\lfloor\frac{\mathrm{V}_{\mathrm{T}}}{\mathrm{I}_{\mathrm{Q}}}+\mathrm{r}_{\mathrm{ex}}+\frac{\mathrm{r}_{\mathrm{bx}}}{(\beta+1)}\right\rfloor,
$$


Therefore, substituting these numerical data, $\mathrm{R}_{\mathrm{I}}=16.15 \Omega$. Fig. 6 shows that the input impedance, $\left|\mathrm{Z}_{\mathrm{i}}\right|$, is resistive at a value close to this up to a frequency of around $250 \mathrm{MHz}$. As expected, at higher frequencies the impedance has an inductive component.

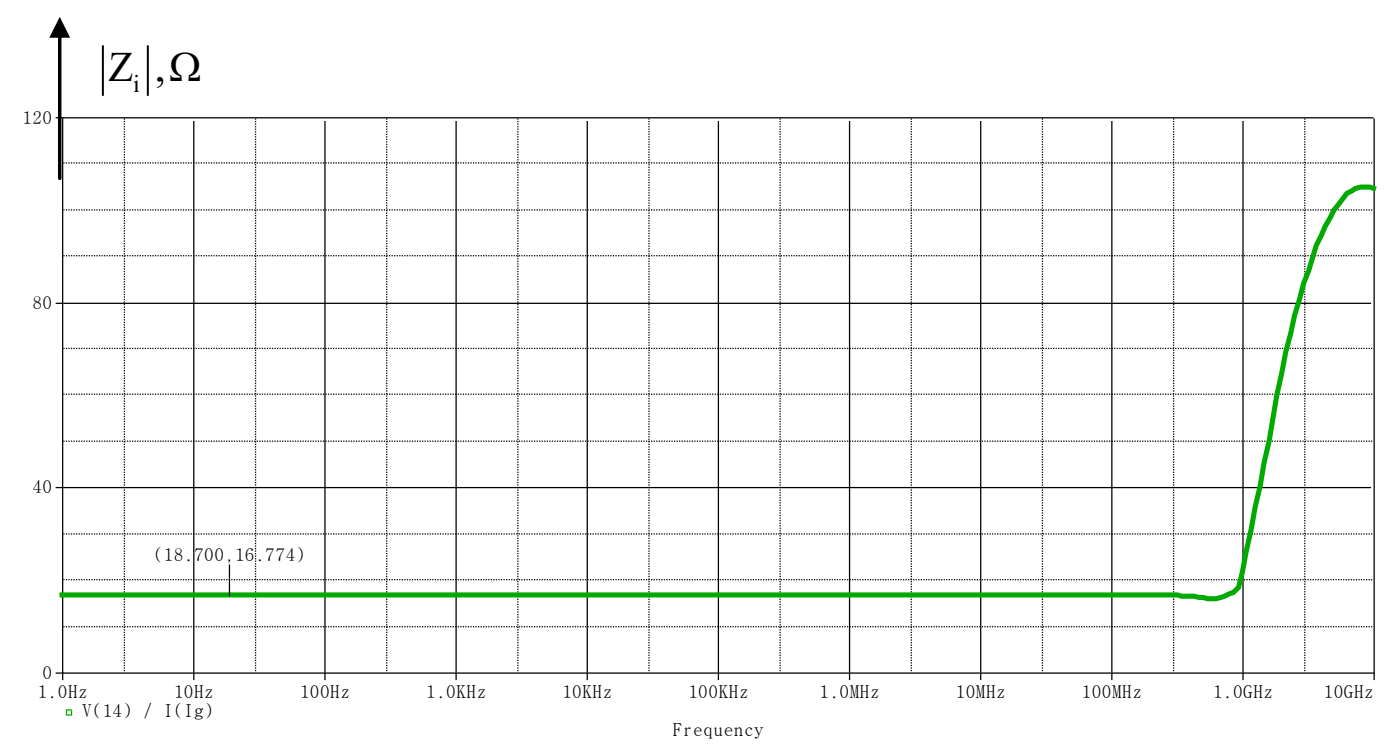

Figure 6: $\left|Z_{\mathrm{i}}\right|$ vs frequency

\section{Design of units $B$ and $C$}

The circuit of unit B with DC bias currents labeled is shown in Fig. 7. The current from the collector of transistor $\mathrm{Q}_{18}$ in unit $\mathrm{A}$ is repeated by a buffered PNP current mirror comprising transistors $\mathrm{Q}_{19}, \mathrm{Q}_{20}, \mathrm{Q}_{21}$, and appears at the collector of the common-base transistor $\mathrm{Q}_{46}$. The bias for this is provided by $\mathrm{Q}_{22}$ and $\mathrm{Q}_{23}$, the current drive for which is supplied by the output of $\mathrm{Q}_{43}$. Transistors $\mathrm{Q}_{27}$ and $\mathrm{Q}_{28}$ are the basic $\mathrm{B} \& \mathrm{~S}$ configuration. The impedance at the collector $\mathrm{Q}_{28}$ is increased above that of a PNP B\&S stage by the inclusion of $\mathrm{Q}_{24}$. However, this requires the presence of $\mathrm{Q}_{25}$ for correct operation. $\mathrm{Q}_{24}$ and $\mathrm{Q}_{26}$ ensure the correct $\mathrm{DC}$ bias for $\mathrm{Q}_{28}$. This configuration should have an incremental output resistance (at the collector of $\mathrm{Q}_{28}$ ) of several $\mathrm{G} \Omega$. However, as shown in Fig. 8, simulation produced a much reduced value: $156 \mathrm{M} \Omega$ (approx). This was due to the low value of the Early voltage of $\mathrm{Q}_{28}, \mathrm{~V}_{\mathrm{AP}}(23 \mathrm{~V})$. Similarly, unit $\mathrm{C}$, the NPN version 
of unit B, is shown in Fig. 9. The current from the collector of $\mathrm{Q}_{17}$ is fed to an NPN buffered current mirror consisting of transistors $\mathrm{Q}_{35}, \mathrm{Q}_{36}$ and $\mathrm{Q}_{37}$. The output of the buffered current mirror is connected to the collector of the common-base transistor $\mathrm{Q}_{47}$. Transistors $\mathrm{Q}_{33}$ and $\mathrm{Q}_{34}$ provide the common-base stage with the correct bias current, the current for biasing these diodes is supplied by the $\mathrm{Q}_{41}$. Transistors $\mathrm{Q}_{29}$ and $\mathrm{Q}_{31}$ form the basic $\mathrm{B} \& \mathrm{~S}$ configuration, but, as described in unit $\mathrm{B}$, the use of transistor $\mathrm{Q}_{32}$ increases the output impedance. However, this requires the presence of $\mathrm{Q}_{48}$ for correct $\mathrm{DC}$ operation. Transistors $\mathrm{Q}_{30}$ and $\mathrm{Q}_{32}$ provide the correct bias for $\mathrm{Q}_{29}$. The output impedance of the unit $\mathrm{C}$ (shown in Fig. 10) should be much higher than the output impedance of unit $B$, because the Early voltage $V_{A N}(90 \mathrm{~V})$, is much higher for NPN devices.

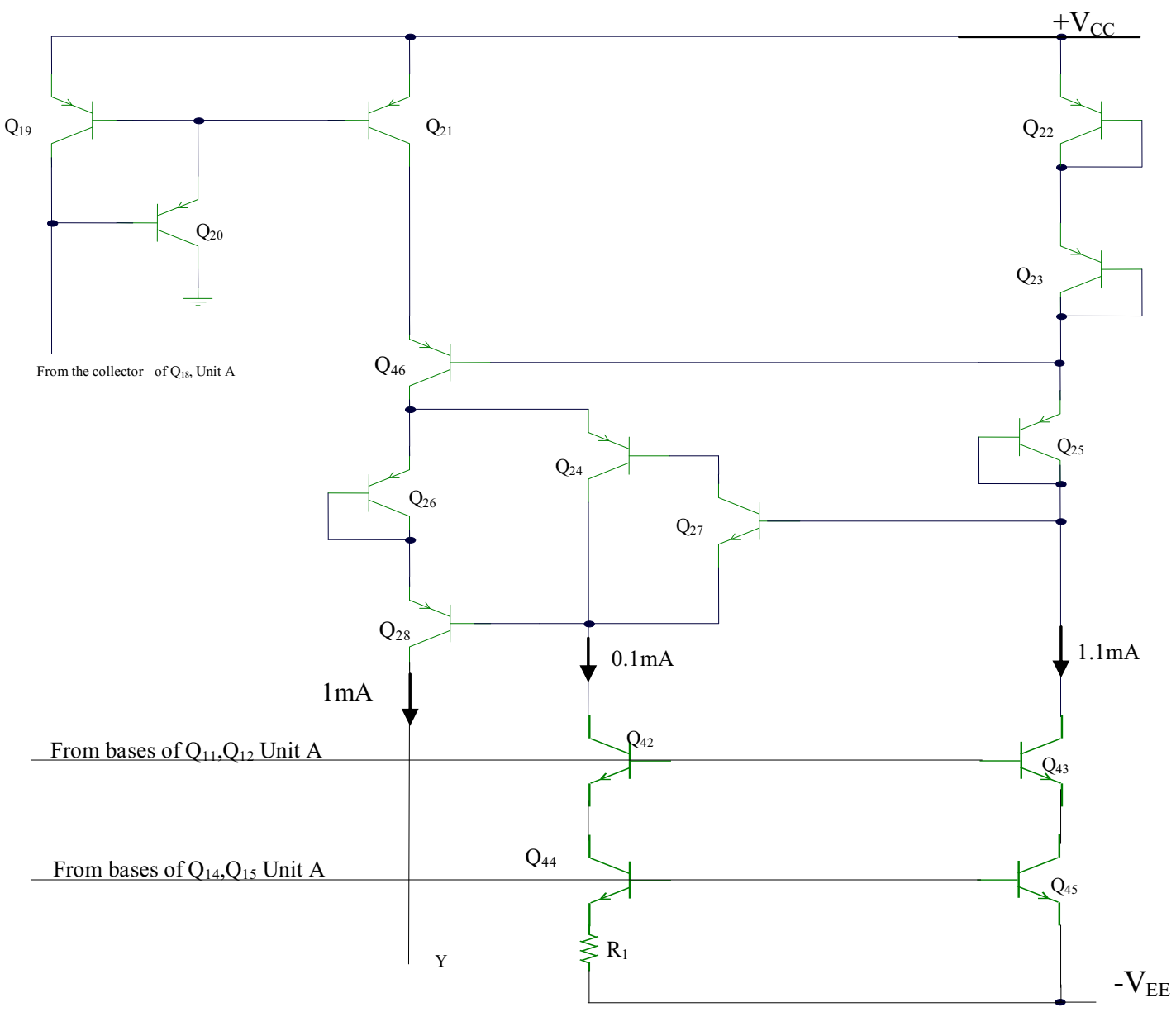

Figure 7: Circuit of unit B of Fig.3 


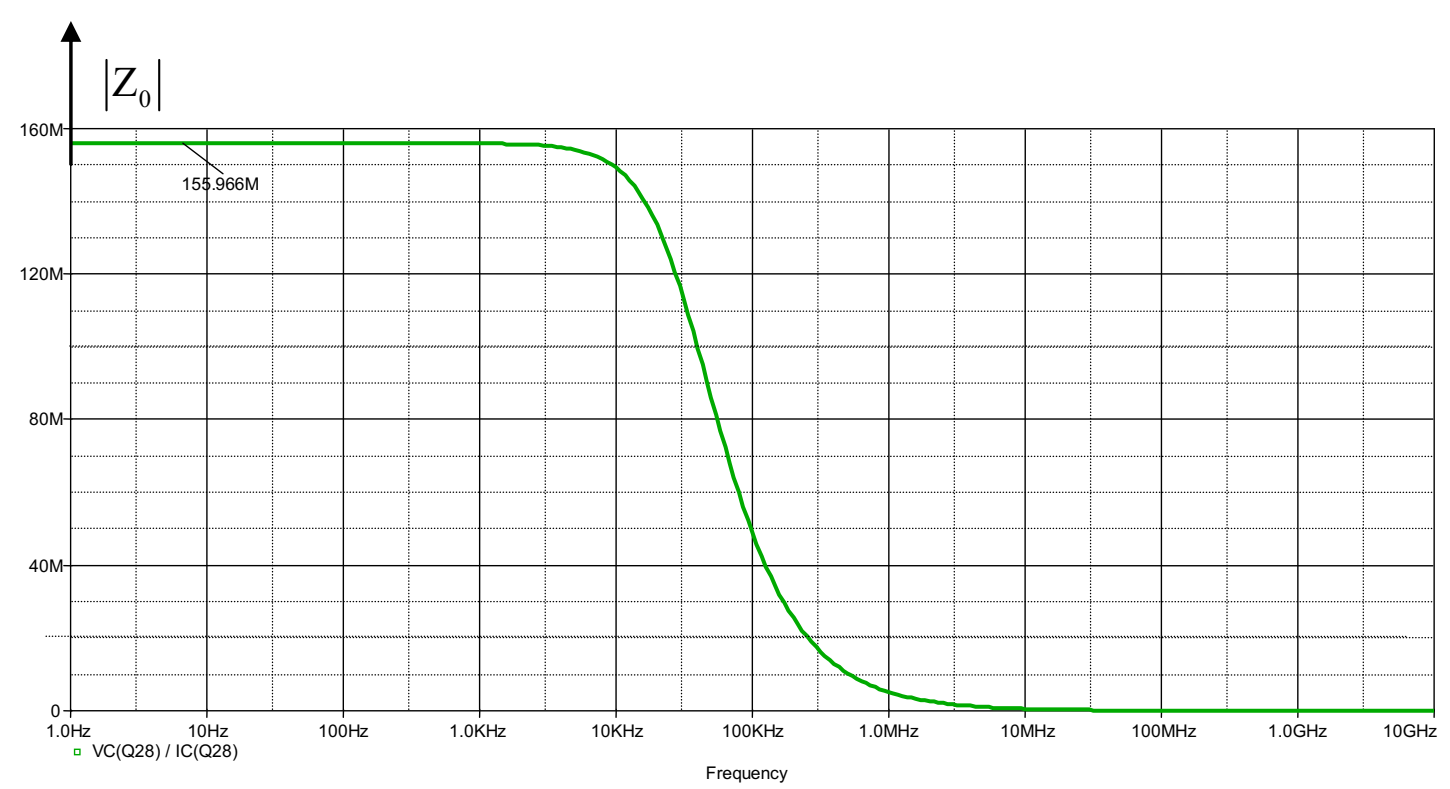

Figure 8: The magnitude of the output impedance at the collector of $Q_{28}$ versus frequency

From the collector of $\mathrm{Q}_{17}$, unit $\Delta$

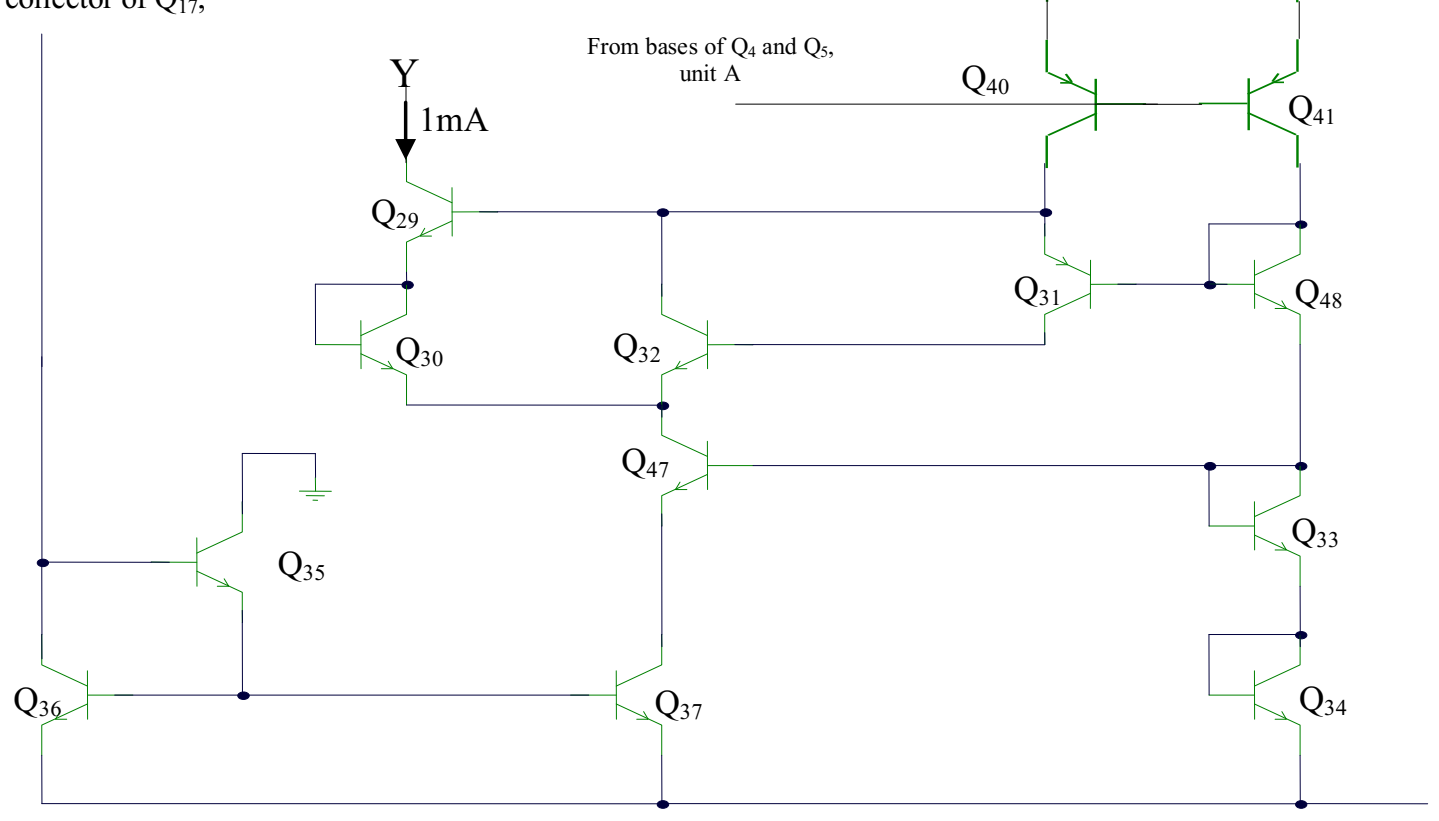

Figure 9: Circuit of unit C of Fig.3 


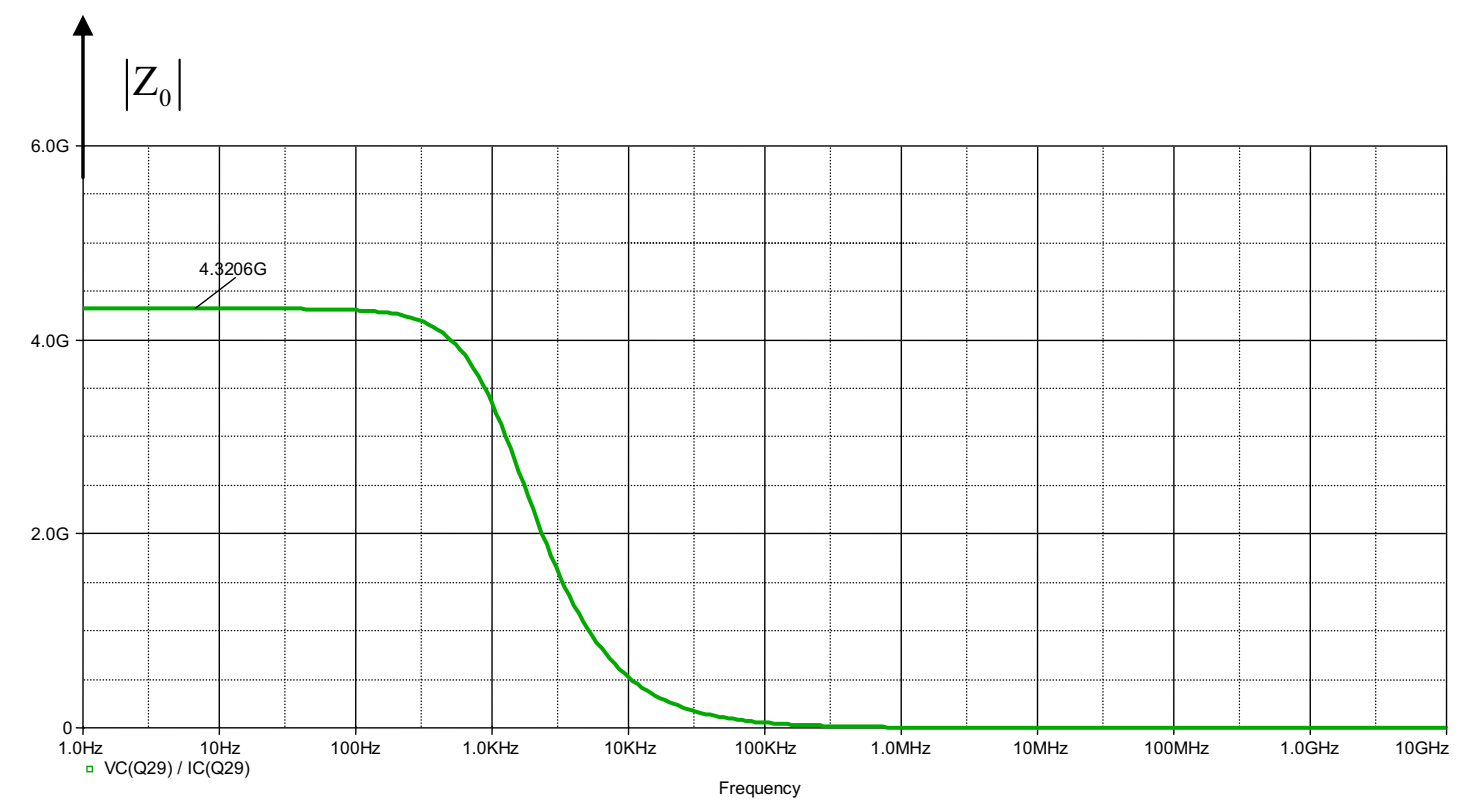

Figure 10: The magnitude of the output impedance at the collector of $Q_{29}$ versus frequency

\section{Design of the transconductance amplifier}

Generally, a transconductance amplifier (or operational transconductance amplifier) is a circuit configuration that produces an output current which is proportional to the difference between two input voltages. The amplitude of the output current, as well as the proportionality between the output current and difference in the two inputs, is controlled by an external bias current $\left(\mathrm{I}_{\text {bias }}\right)$. Fig. 11 is a schematic diagram of a typical transconductance amplifier [19].

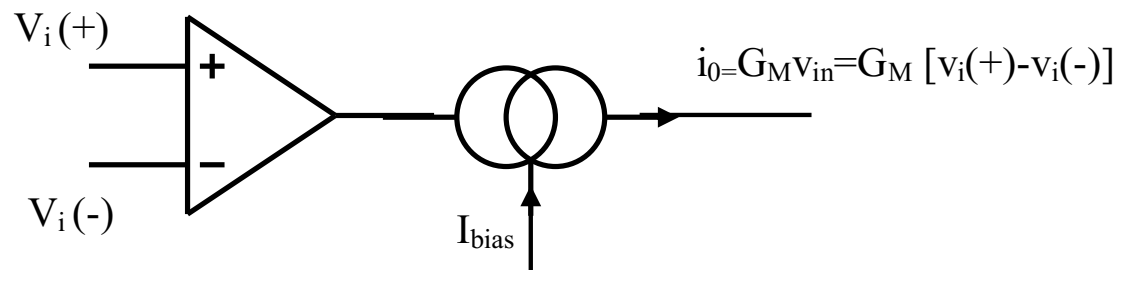

Figure 11: Schematic diagram of a typical transconductance amplifier 
The scheme adopted in the commercially available unit LM380 (National Semiconductor) is shown in Fig. 12. The output currents of the two BJTs of a long-tailed pair feed complementary current mirrors. The outputs of the two mirrors, assumed ideal for descriptive purposes, are combined to give an overall output current $i_{0}$ which is given by:

$\mathrm{i}_{0}=\mathrm{g}_{\mathrm{m}} \mathrm{V}_{\mathrm{in}}$,

where $\mathrm{G}_{\mathrm{M}=\mathrm{g}_{\mathrm{m}}}=\mathrm{I}_{\mathrm{bias}} / 2 \mathrm{~V}_{\mathrm{T}}$ is the mutual conductance of each of the long-tailed pair BJTs at the operating current $\mathrm{I}_{\text {bias }} / 2$. Hence, $\mathrm{i}_{0}=\mathrm{G}_{\mathrm{M}} \mathrm{v}_{\text {in }}=\mathrm{g}_{\mathrm{m}} \mathrm{v}_{\text {in }}=\mathrm{I}_{\text {bias }} \mathrm{v}_{\text {in }} / 2 \mathrm{~V}_{\mathrm{T}}$. The choice of $\mathrm{I}_{\text {bias }}$ consequently determines $\mathrm{G}_{\mathrm{M}}$. However, the circuit of Fig. 12 is not sufficient for the present purposes because of the relatively low impedances looking-in at the bases of the long-tailed pair transistors.

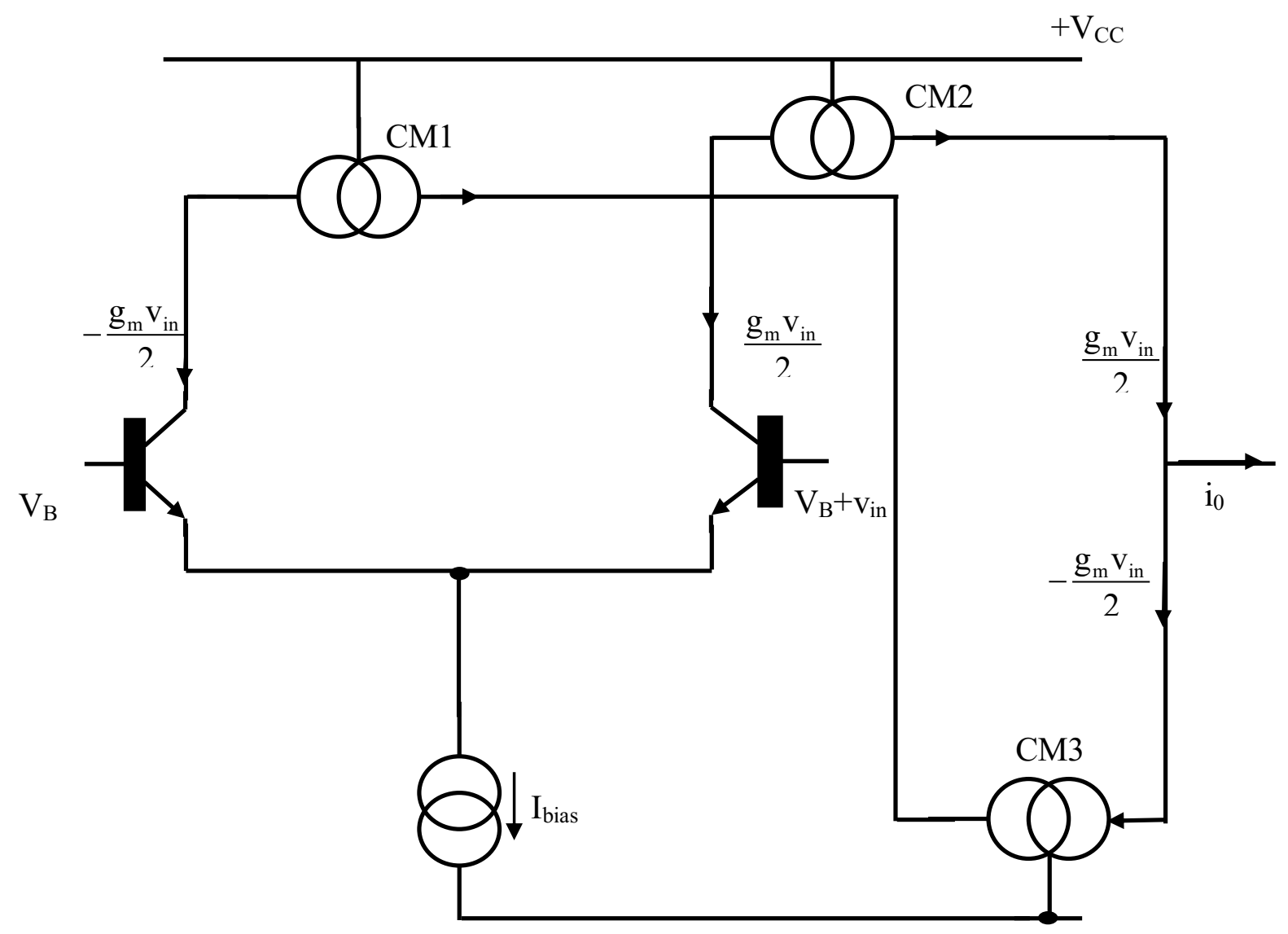

Figure 12: Circuit configuration of a typical transconductance amplifier 
A solution to that problem is to drive the bases by n-channel MOSFET source followers. However, these have a voltage gain less than one because of the effect of source substrate bias. That effect can be reduced by making the source-followers into hybrid complementary source-followers by the inclusion of PNP transistors in their drain leads.

The final design is shown in Fig. 13. The appropriate $I_{\text {bias }}(=2 m A)$ is supplied by a modified version of the '6-pack' current mirror [20]. The outputs of the long-tailed pair feed modified Wilson current mirrors. Resistors $\mathrm{R}_{270}$ and $\mathrm{R}_{280}$ are chosen so as to equalize the currents in the drains of $\mathrm{M}_{1}$ and $\mathrm{M}_{2}$ and the collector of $\mathrm{Q}_{270}$ and $\mathrm{Q}_{280}$. The output impedance of the configuration is the parallel combination of the output of a PNP and an NPN current mirror. This is much greater, by several orders of magnitude, than the input impedance of unit A.

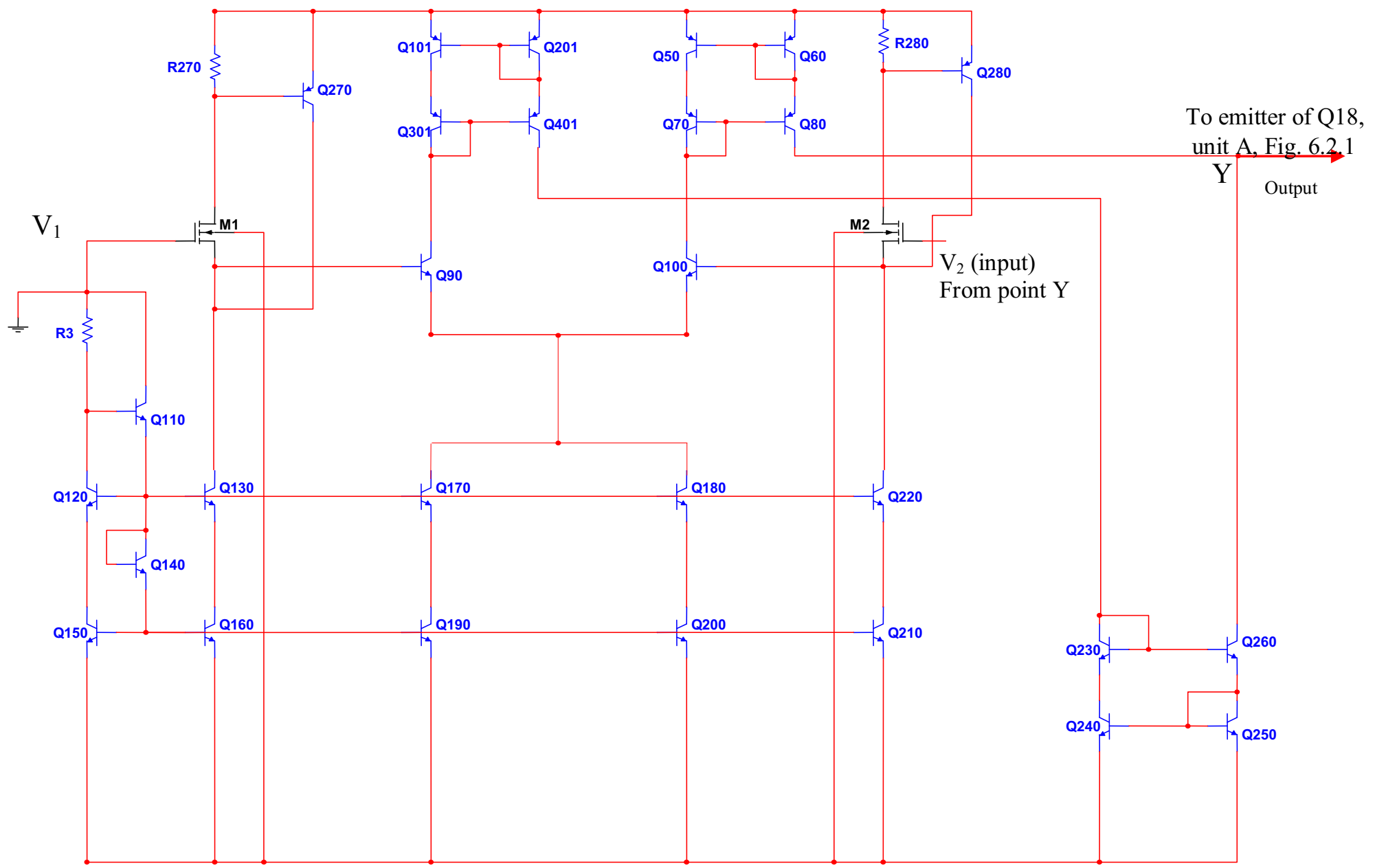

Figure 13: Circuit of the high input impedance transconductance amplifier 

Fig. 14 presents the transconductance amplifier transfer characteristic for the unit $\mathrm{D}$, which was obtained by grounding $\mathrm{V}_{1}$ and varying $\mathrm{V}_{2}$ over the range $-0.5 \mathrm{~V}$ to $+0.5 \mathrm{~V}$.

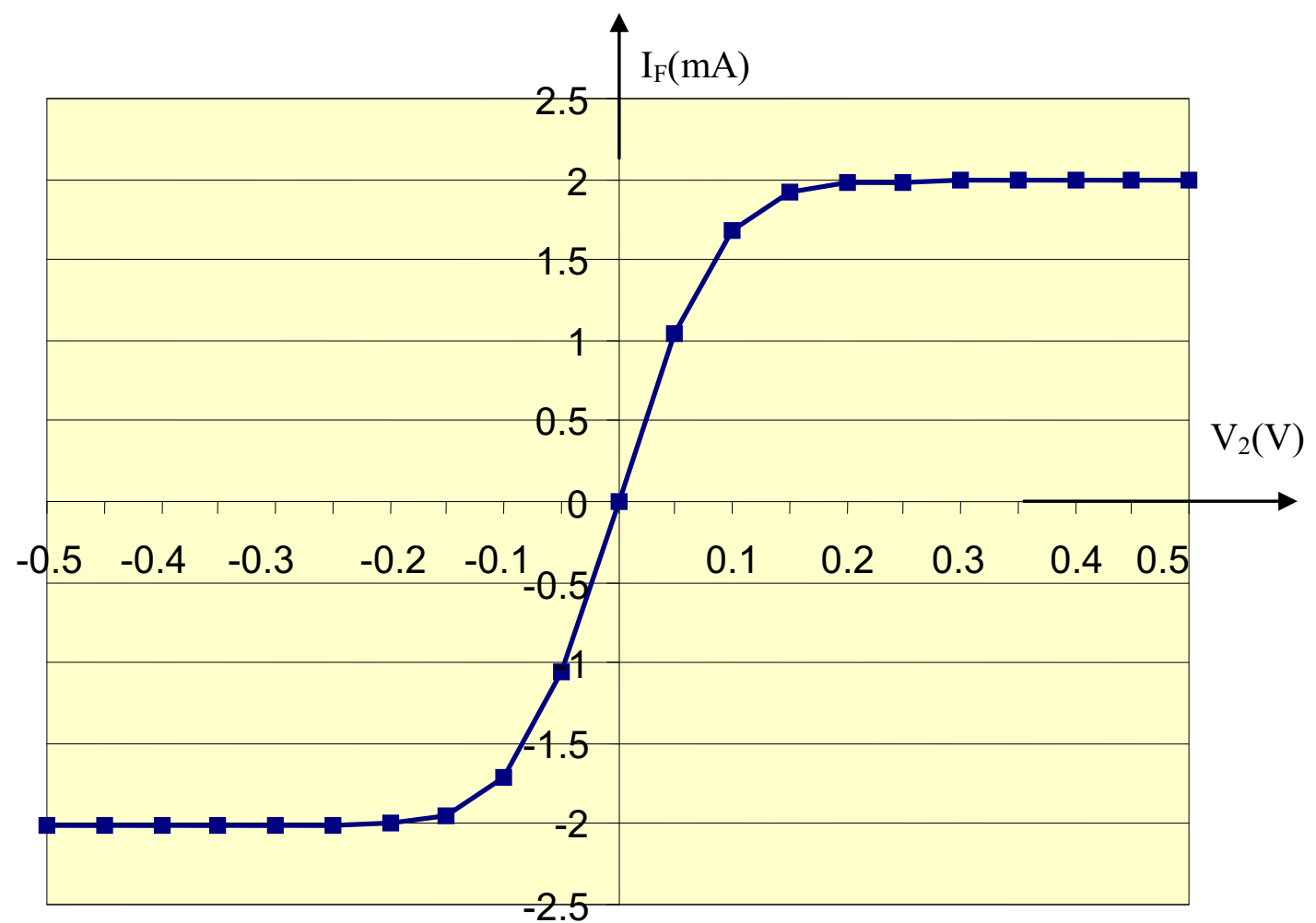

Figure 14: The transconductance amplifier transfer characteristic for $I_{b i a s}=2 \mathrm{~mA}$

\section{System performance}

Following the earlier discussion of the individual sub-units of the tissue driver system, Figs. 15 and 16 shown below, for reference purposes, the interconnected sub-circuits. For clarity, transistor numbers are not shown. 

$+\mathrm{V}_{\mathrm{CC}}$

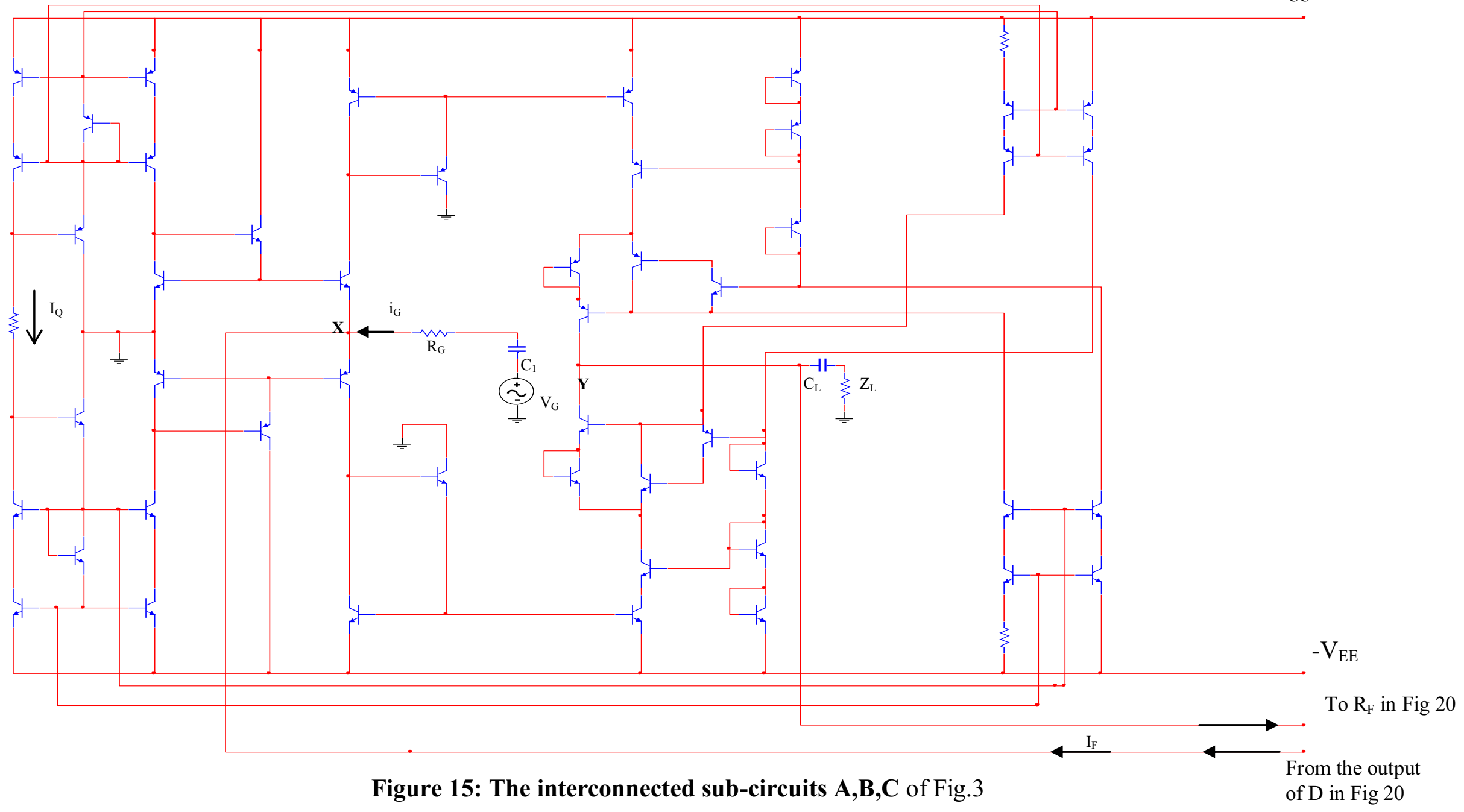




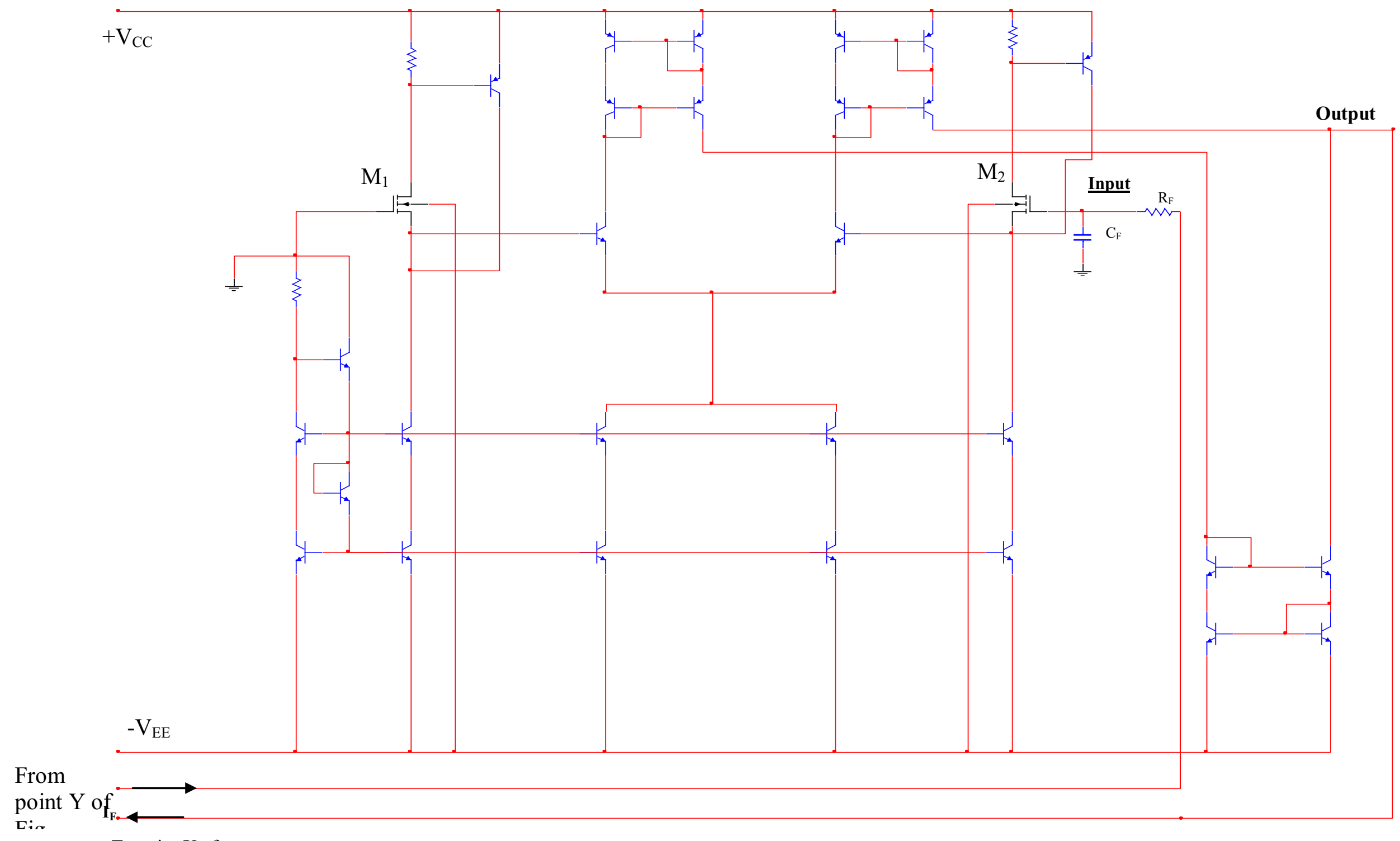

To point $\mathrm{X}$ of

Figure 16: The Sub-circuit D (Transconductance amplifier) of Fig.3

Fig6.5.1(a) 
With no input signal, the DC level at point $\mathrm{Y}$ is shown in Fig. 17 across the temperature range of $-40^{\circ} \mathrm{C}$ to $+85^{\circ} \mathrm{C}$. It can be seen that the $\mathrm{DC}$ output is in the region of $-1.6 \mathrm{mV}$ at room temperature. The increase with temperature can be attributed mainly to the temperature dependence of $\mathrm{G}_{\mathrm{M}}$, which for a fixed operating current in the transconductance amplifier is proportional to the absolute temperature.

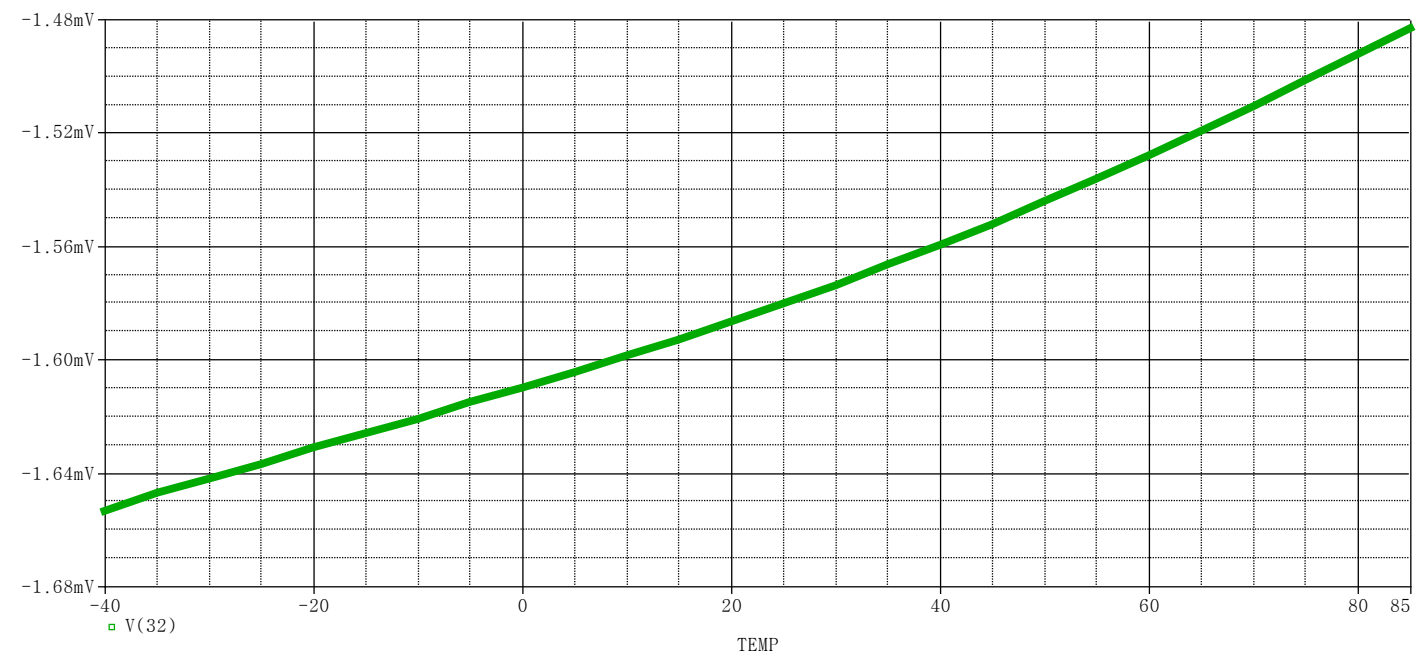

Figure 17: Temperature variation of voltage at point $Y$

In the simulation measurements the respective devices (BJTs and MOSFETs) in the transconductance amplifier were assumed to be perfectly matched. This, of course, would not normally be the case in a practical implementation of the system. To check the effect of mismatch between the transistors a variable DC voltage was applied to the gate of MOSFET $\mathrm{M}_{1}$.

Fig. 18 shows the plot of the magnitude $\left|Z_{0}\right|$ of the impedance seen by the tissue sample as a function of frequency. It can be seen that the $\left|\mathrm{Z}_{0}\right|>16 \mathrm{M} \Omega$ at $100 \mathrm{KHz}$. The results were obtained using $\mathrm{R}_{\mathrm{F}}=20 \mathrm{M} \Omega, \mathrm{C}_{\mathrm{F}}=1 \mu \mathrm{F}, \mathrm{C}_{\mathrm{IN}}=1000 \mu \mathrm{F}$ and $\mathrm{R}_{\mathrm{IN}}=2 \mathrm{k} \Omega$. 


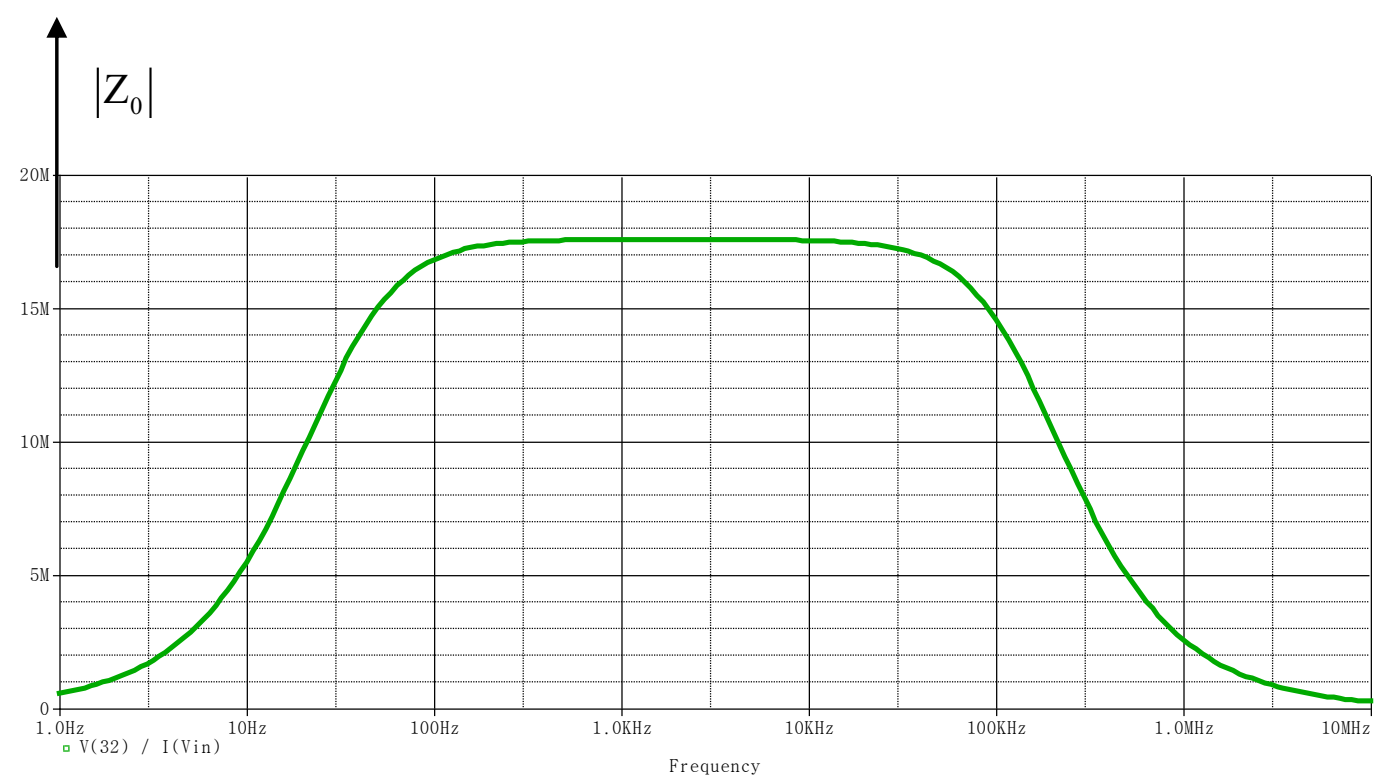

Figure 18: The magnitude of $\mathrm{Z}_{0}$

Under these conditions there is no significant AC feedback for frequencies above $100 \mathrm{~Hz}$ and the source impedance seen by the tissue sample is effectively $20 \mathrm{M} \Omega$ in parallel with the output resistances of units $\mathrm{B}$ and $\mathrm{C}$ which, by design, exceed $100 \mathrm{M} \Omega$ each. The DC drop across $\mathrm{R}_{\mathrm{F}}$ due to MOSFET gate current is negligible.

In order to make a further evaluation of the performance of the tissue driver system some tests were performed involving the connection of parasitic resistances and capacitances that can exist across the filter capacitor and resistor, $\mathrm{C}_{\mathrm{F}}$ and $\mathrm{R}_{\mathrm{F}}$ respectively, in a practical implementation.

Firstly, a $20 \mathrm{M} \Omega$ resistor is connected in parallel with the feedback capacitor $\mathrm{C}_{\mathrm{F}}$, as shown in Fig 19, to simulate capacitor leakage resistance. The results of this simulation are presented in Fig. 20. We can conclude that the added resistor has no noticeable effect. This is not unexpected, because over the frequency range of interest the impedance of $\mathrm{C}_{\mathrm{F}}$ is very much smaller than that of $\mathrm{R}_{\mathrm{CL}}$.

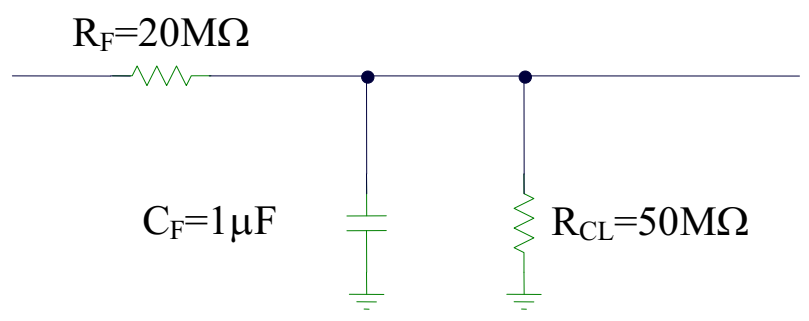

Figure 19: The testing scheme for the feedback capacitor $C_{F}$ 


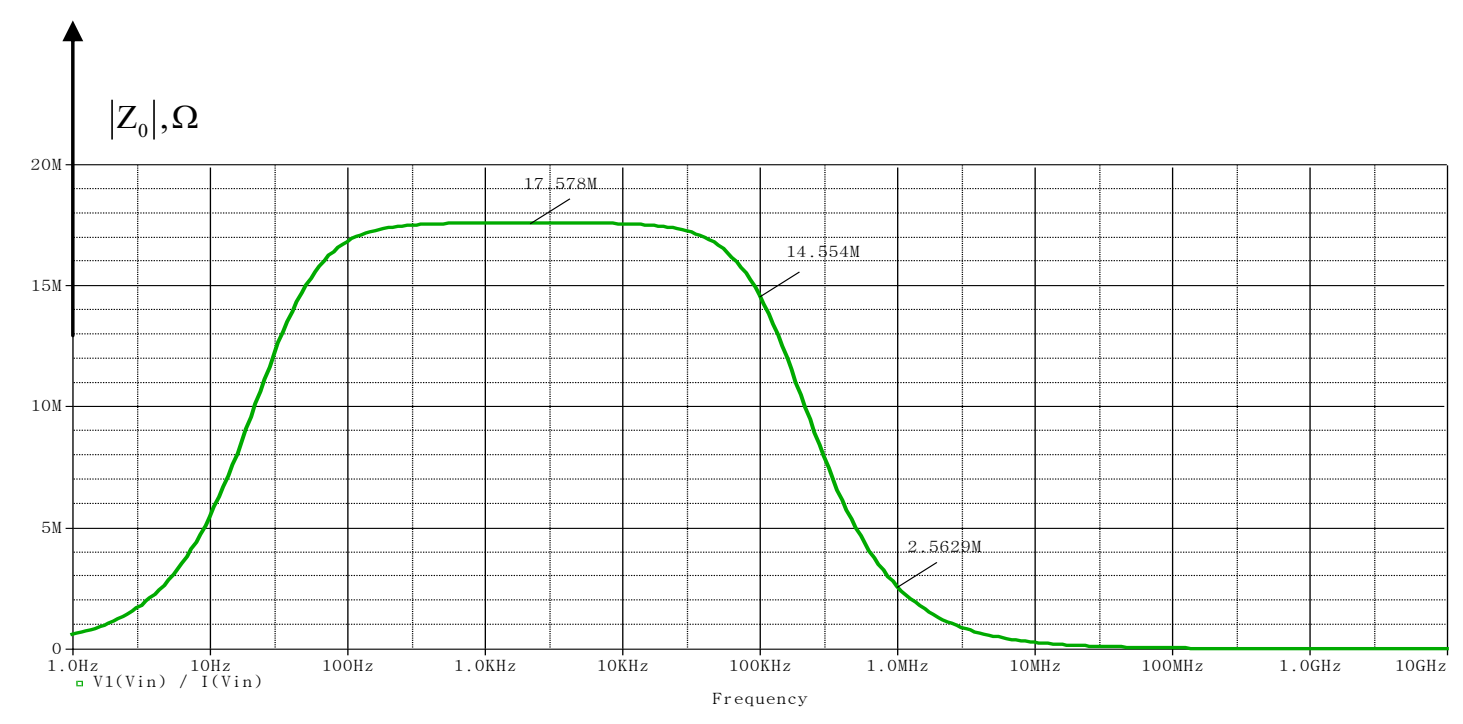

Figure 20: The output impedance of the tissue driver system when a parasitic resistor $R_{C L}=50 M \Omega$ is connected in parallel with the filter capacitor $C_{F}$

A further test involved the connection of a parasitic capacitor of $1 \mathrm{pF}$ in parallel with $\mathrm{R}_{\mathrm{F}}$. This could represent the actual end-to-end capacitance of a real resistor or stray capacitance or the effect of external loading. Fig. 21 shows the result of this test. It can be seen that the reduction in the bandwidth of $\left|Z_{0}\right|$ makes the proposed system of very limited use (Output impedance of $150 \mathrm{~K} \Omega$ at $1 \mathrm{MHz}$ ). Consequently, a modification was made and the improved system is presented in Section 8.

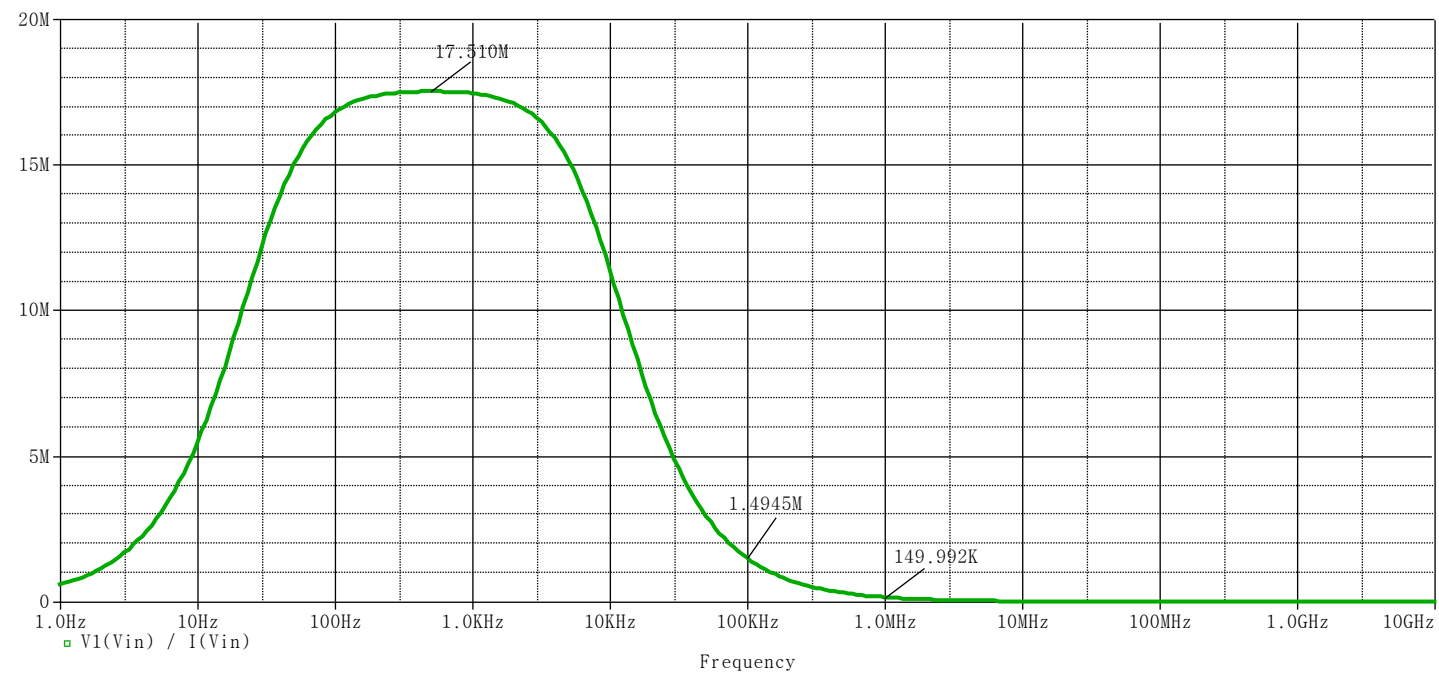

Figure 21: The output impedance of the testing scheme using a parasitic capacitor across the feedback resistor 


\section{Performance of the improved system}

A modified tissue driver system is shown in Fig. 23. It differs from the original system by the addition of an output buffer amplifier, OP-AMP (type AD-8038), connected as a voltage-follower (Transconductance amplifier). The simulated values of the impedance at point $\mathrm{Y}$ with the load $\left(\mathrm{C}_{\mathrm{L}}, \mathrm{R}_{\mathrm{L}}\right)$ disconnected are shown in Fig. 22. As it can be seen, $\left|\mathrm{Z}_{0}\right|$ at point $\mathrm{Y}$ is $2.6 \mathrm{M} \Omega$ (from $150 \mathrm{~K} \Omega$ in Fig. 21 ) at $1 \mathrm{MHz}$.

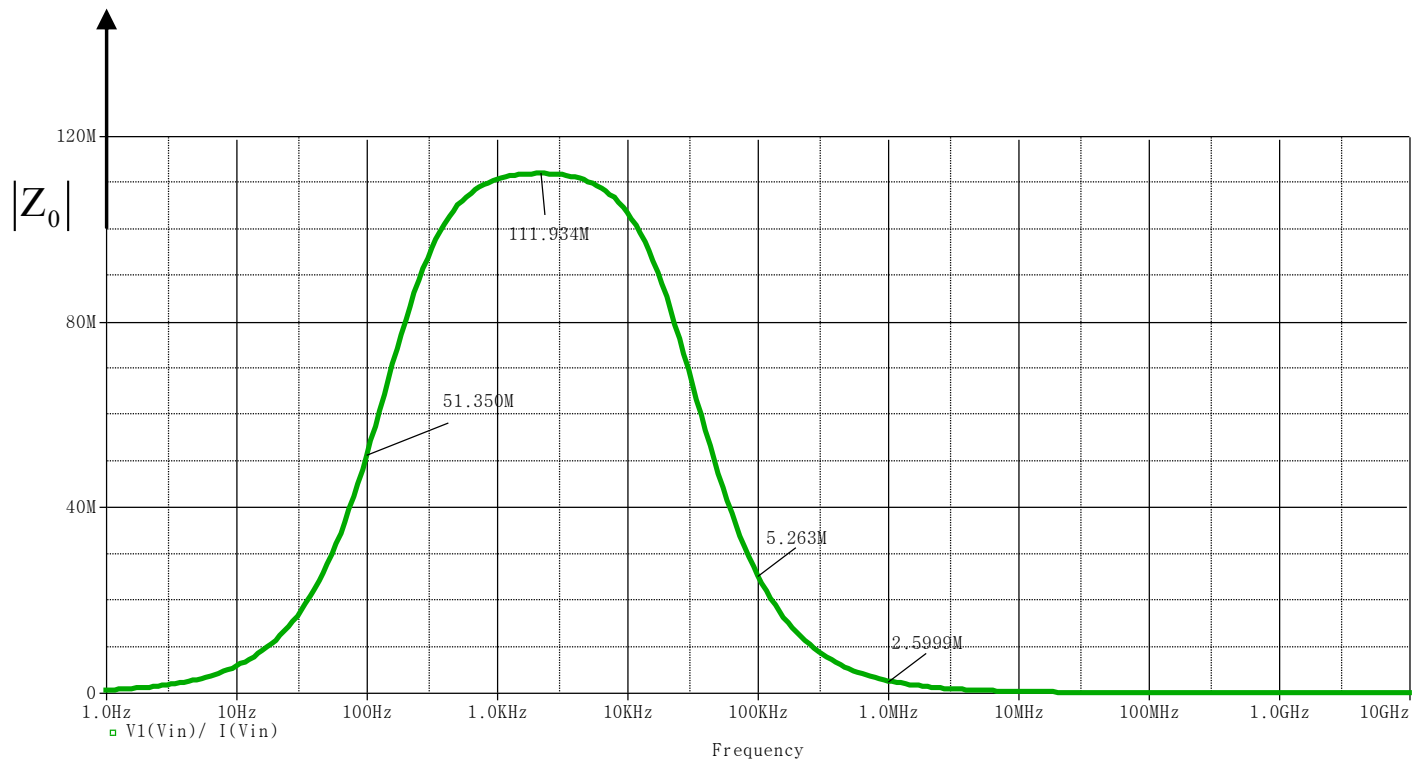

Figure 22: Impedance $\left|Z_{0}\right|$ at $Y$ with the load disconnected and the buffer stage added 


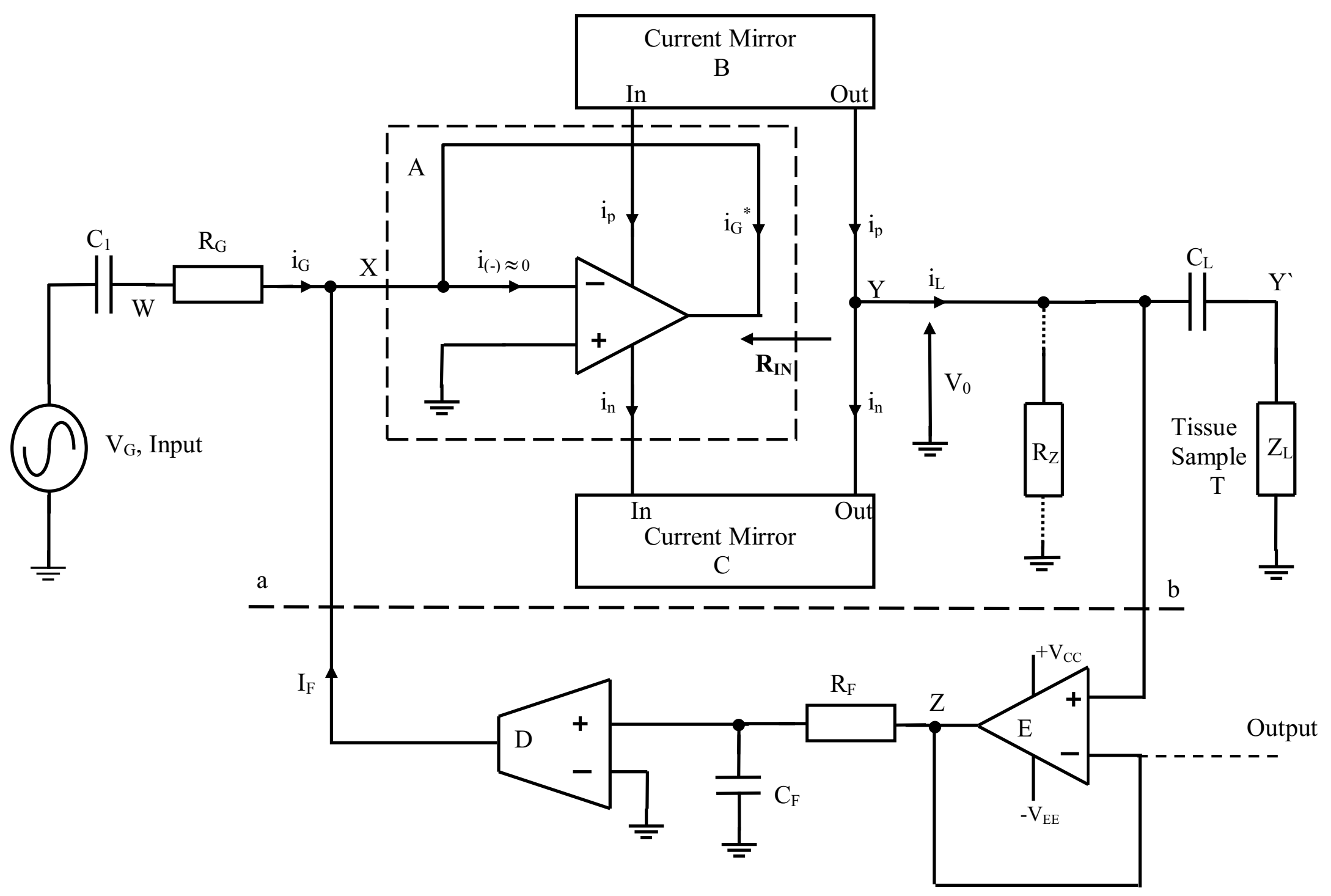

Figure 23: The modified system including an added unit, E [21, 22] 


\begin{tabular}{|c|c|c|c|}
\hline & D. Shao [8] & $\begin{array}{c}\text { Constantinou, L. et. al. } \\
\text { [7] }\end{array}$ & This work \\
\hline $\begin{array}{c}\text { Output Impedance @ } \\
1 \mathrm{MHz}\end{array}$ & $<50 \mathrm{~K} \Omega$ & $<500 \mathrm{~K} \Omega$ & $2.6 \mathrm{M} \Omega$ \\
\hline
\end{tabular}

\section{Table I: Comparison table with other related published work}

\section{Conclusion}

A novel current source suitable for medical applications, EIT in particular, has been proposed. The system level current source of Fig. 3 was designed and then implemented in bipolar technology as shown in Fig. 23. Simulation of this novel current source tissue architecture demonstrated that its performance met the specification currently set by the EIT medical instrumentation. The phase shift of $180^{\circ}$ between the input and output signals is not important, but if desired can be fixed by using an inverting amplifier at the input. The amplitude reduction between the input and output signals can be attributed to the non-

unit gain of current mirrors feeding point $\mathrm{Y}$. However, this voltage reduction can be compensated for by using a follower with gain in place of unit E.

This work is on-going and the design will be fabricated in silicon shortly, and these results will be presented in a follow-up publication by the authors.

\section{References:}

[1] Gray R. Paul, Hurst J. Paul, Lewis H. Stephen, Meyer G. Robert,'Analysis and Design of Analog Integrated Circuits', John Wiliey and Sons, 1993 pp269

[2] Sedra A, Smith K, 'Microelectronic Circuits', Oxford University press 2004, pp.649

[3] Greeneich W. Edwin,'Analog Integrated Circuits', Chapman \& Hall, 1996, pp 50

[4] C. Toumazou, F.J.Lidgey D.G. Haigh, 'Analogue IC Design: the current mode approach', Peter Peterginus Ltd, 1990, pp127-136,239-241 
[5] Christofer William Lawrence Denyer,'Electronics for Real Time and ThreeDimensional Electrical Impedance Tomographs', Oxford Brookes University $\mathrm{PhD}$ thesis, January 1996, pp9-16, pp23-24, pp68-91.

[6] David S Holder,'ELECTRICAL IMPEDANCE TOMOGRAPHY:Methods, History and Applications', Institute of Physics publishing, London, 2005

[7] Constantinou, L.; Triantis, I.F.; Bayford, R.; Demosthenous, A., "High-Power CMOS Current Driver With Accurate Transconductance for Electrical Impedance Tomography," Biomedical Circuits and Systems, IEEE Transactions on , vol.PP, no. 99 , pp. 1,1

[8] Dechun Zhao, "High output-impedance current source for electrical impedance tomography," Biomedical Engineering and Informatics (BMEI), 2011 4th International Conference on , vol.2, no., pp.1106,1109, 15-17 Oct. 2011

[9] I. Frerichs, 'Electrical Impedance Tomography (EIT) in applications related to lung and ventilation: A review of experimental and clinical activities', Physiol. Meas. 21(2) (2000), pp. R1-R21.

[10] G. Hahn, A. Just, T. Dudykevych, I. Frerichs, J. Hinz, M. Quintel, and G. Hellige, 'Imaging pathologic pulmonary air and fluid accumulation by functional and absolute EIT', Physiol. Meas. 27(5) (2006), pp. S187-S198.

[11] D. Anton, M. Balleza, J. Fornos, B. Kos, P. Casan, and P.J. Riu, 'A compact EIT system for ventilation monitoring in COPD patients', IFMBE Proc. 17 (2007), pp. 564-567.

[12] Z. Zhao, K. Möller, D. Steinman, I. Frerichs, and J. Guttmann, Evaluation of an electrical impedance tomography-based global inhomogeneity index for pulmonary ventilation distribution, Intensive Care Medicine 35(11) (2009), pp. 1900-1906.

[13] K Hayatleh, N Terzopoulos, B Hart, ' Designing a very high output resistance current source for medical applications', Published online in 'International Journal of Electronics', May 2012

[14] Graeme J. ,'Applications of Operational Amplifiers',McGraw-Hill, 1973 ,Chp. 3, pp 93-94

[15] Hart B. L. and Barker R.W.J, ' A precision bilateral voltage-current Converter', IEEE J. Solid State Circuits, 1975, SC 10, pp 501-503

[16] Rao, M.K.N. and Haslett j. W., ' Class AB bipolar voltage-current converter', Electronics Letters, 1978, 14, pp.762-764 
[17] N Terzopoulos, 'High Output Resistance Current Drive Circuits for Medical Applications', PhD Thesis, Oxford Brookes University, 2006

[18] Baxandall P.J., and Swallow E.W., 'Constant current source with unusually high internal resistance and good temperature stability', Electronic Letters, 1966,

[19] E.W.Greeneich ,'Analog Integrated Circuits', Chapman \& Hall, 1996 pp 183-194

[20] Tammam A A, Hayatleh K, Hart B and Lidgey F J, 'A new current-feedback operational amplifier with a high CMRR', Electronics letters, pp 1483, Vol 39, no 21 , October $16^{\text {th }} 2003$

[21] N Terzopoulos, K Hayatleh, B Hart, F J Lidgey ‘ A Novel Bipolar-Drive circuit for Medical Applications', Published in 'Physiological Measurement' Journal, Vol 26, p21-27, October 2005

[22] N Terzopoulos, K Hayatleh, B Hart, F J Lidgey ' Novel current driver suitable for EIT applications'Published in 6th International Conference on Biomedical Applications of Electrical Impedance Tomography University College London, June 2005

[23] A S Ross, G J Saulnier, J C Newell, D Isaacson "Current source design for electrical impedance tomography", Physiological Measurement, Volume 24, Number 2, pp.509, Apr. 2003. 